\title{
FRIT SELECTION TO SUPPORT STEKLO METALLICHESKIE KONSTRUKTSII (SMK) MELTER TESTING WITH SRNL FEEDS
}

J.H. Gillam, Jr.

K.M. Fox

T.B. Edwards

D.K. Peeler

July 2007

Materials Science and Technology Savannah River National Laboratory Aiken, SC 29808 
WSRC-STI-2007-00363

Revision 0

DISCLAIMER

This report was prepared by Washington Savannah River Company (WSRC) for the United States Department of Energy under Contract No. DE-AC09-96SR18500 and is an account of work performed under that contract. Neither the United States Department of Energy, nor WSRC, nor any of their employees makes any warranty, expressed or implied, or assumes any legal liability or responsibility for the accuracy, completeness, or usefulness, of any information, apparatus, or product or process disclosed herein or represents that its use will not infringe privately owned rights. Reference herein to any specific commercial product, process, or service by trademark, name, manufacturer or otherwise does not necessarily constitute or imply endorsement, recommendation, or favoring of same by WSRC or by the United States Government or any agency thereof. The views and opinions of the authors expressed herein do not necessarily state or reflect those of the United States Government or any agency thereof.

\section{Printed in the United States of America \\ Prepared For U.S. Department of Energy}

The Savannah River National Laboratory is operated for the U.S. Department of Energy by Washington Savannah River Company. 
Keywords: high level waste, glass, melter demonstrations

Retention: permanent

\title{
FRIT SELECTION TO SUPPORT STEKLO METALLICHESKIE KONSTRUKTSII (SMK) MELTER TESTING WITH SRNL FEEDS
}

\author{
J.H. Gillam \\ K.M. Fox \\ T.B. Edwards \\ D.K. Peeler
}

July 2007 


\section{REVIEWS AND APPROVALS}

\section{AUTHORS:}

J.H. Gillam, Jr., Process Science and Engineering

Date

K.M. Fox, Materials Science and Technology

Date

T.B. Edwards, Statistical Consulting

Date

D.K. Peeler, Process Science and Engineering

Date

\section{TECHNICAL REVIEWER:}

J.D. Newell, Process Science and Engineering

Date

\section{APPROVERS:}

D.A. Crowley, Manager, Stabilization Science Research

Date

J.C. Marra, Materials Science and Technology

Date

International Programs Coordinator

R.E. Edwards, Manager, Process Science and Engineering

Date 
WSRC-STI-2007-00363

Revision 0

\section{EXECUTIVE SUMMARY}

Four frits were developed for possible use in melter testing with V.G. Khlopin Radium Institute's Steklo Metallicheskie Konstruktsii (SMK) melter. The frits were selected using Measurement Acceptability Region (MAR) assessments of an array of frit formulations and two Sludge Batch 5 (SB5) flowsheets, one with the anticipated effect of the implementation of Al-dissolution and one without. Test glasses were fabricated in the laboratory to verify that the property and performance models used to select the frits were applicable to the frit/sludge systems of interest.

Each of the four frits was tested with each of the two sludges at two different waste loadings, for a total of 16 test glasses. Each glass was both quenched and subjected to the canister centerline cooled (CCC) thermal profile. Samples of each glass were examined for crystallization by X-ray diffraction (XRD) and durability using the Product Consistency Test (PCT). The quenched version of each glass appeared amorphous by visual observations, although XRD results indicated a small amount of crystallization in four of the quenched glasses. Visual observations identified surface crystallization on the CCC versions of all 16 glasses. Three of the 35\% waste loading (WL), CCC glasses were found to contain trevorite (a spinel) by XRD, and all of the 40\% WL CCC glasses were found to contain trevorite. Nepheline was not observed in any of the test glasses, which is consistent with model predictions.

In terms of durability, any of the four frits tested would produce an acceptable glass with the sludge compositions used at 35\% or $40 \% \mathrm{WL}$. The PCT results for the study glasses show that each glass has a durability that is considered very acceptable, with normalized releases for boron that are better than an order of magnitude below that of the Environmental Assessment (EA) glass standard. Only two of the study glasses showed measurable differences in PCT response between the quenched and CCC heat treatments.

Overall, there was little difference in the performance of the four frits across the SB5 compositions and waste loadings tested. Each frit tended to provide good results (in terms of crystallization and durability) for some combinations of sludge composition and waste loading, while not performing as well as some of the other frits for other combinations. Because it was difficult to identify the better performing frits based on these data, the selection was made with the intent of better determining the effect of frit composition on melt rate. Recent frit development efforts for DWPF have identified frits with a higher concentration of $\mathrm{B}_{2} \mathrm{O}_{3}$ as being beneficial for improving melt rate for sludges with a high $\mathrm{Al}_{2} \mathrm{O}_{3}$ concentration. Frits 520, 503 and 517 are therefore recommended for the SMK melter testing because they cover a relatively wide range of $\mathrm{B}_{2} \mathrm{O}_{3}$ concentrations $(8,14$ and $17 \mathrm{wt} \%$, respectively). This selection of frits also eliminates the frit that resulted in the poorest normalized release for boron seen in this study (1.32 g/L for Frit 521 at 40\% WL with the "SB5 without Aldissolution” sludge). 


\section{TABLE OF CONTENTS}

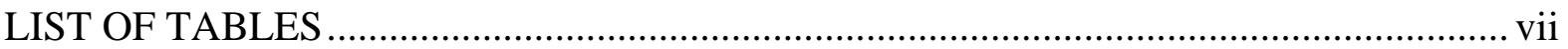

LIST OF ABBREVIATIONS ................................................................................. viii

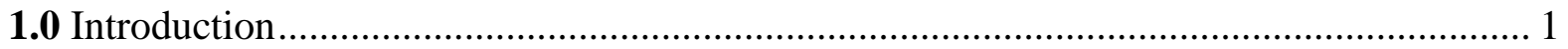

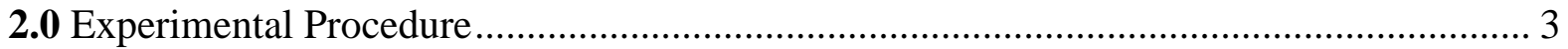

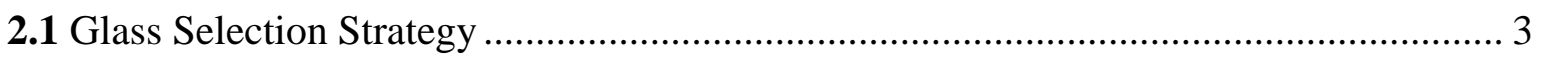

2.2 Target Compositions of Selected Glasses ............................................................ 5

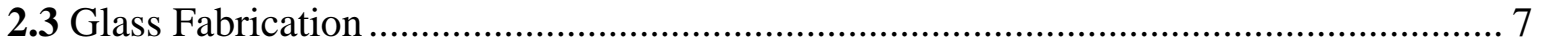

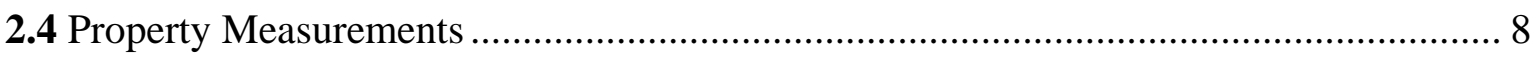

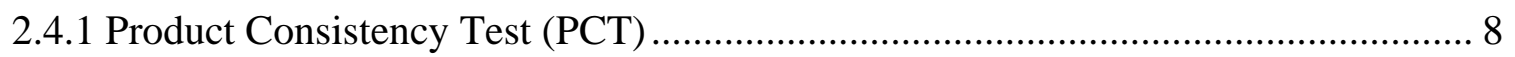

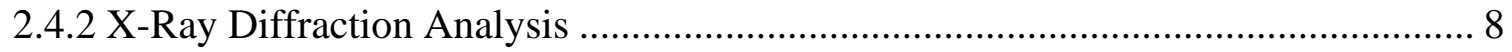

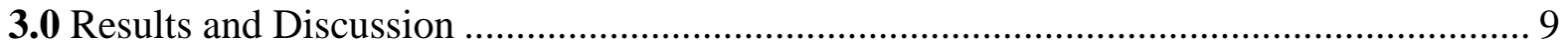

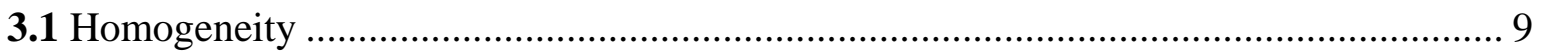

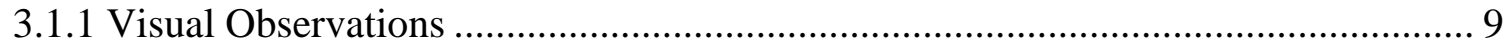

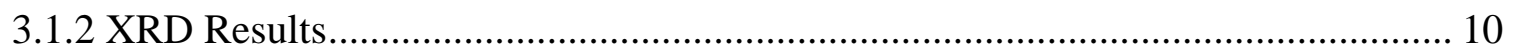

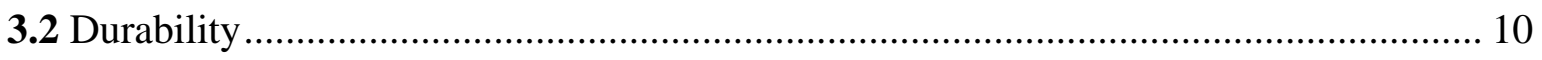

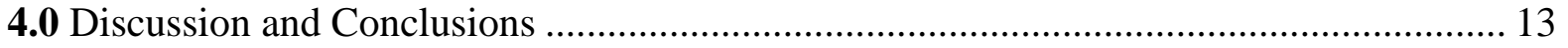

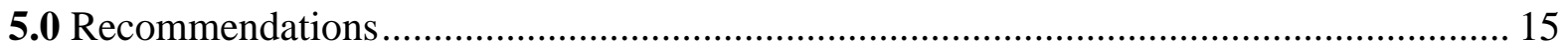

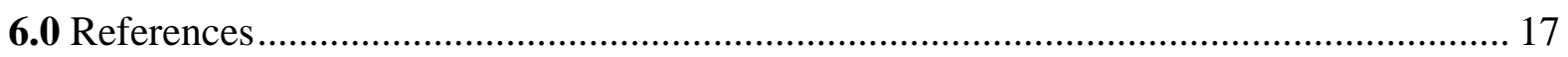

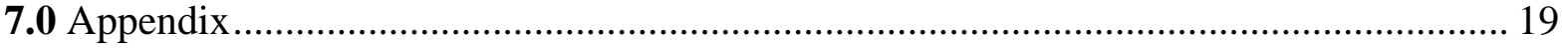




\section{LIST OF TABLES}

Table 2-1. Target sludge compositions (in wt\% oxides) for the melter test glasses..............................................

Table 2-2. Ranges of frit component concentrations used in the paper study. .....................................................

Table 2-3. Selected results of the paper study assessment for frit selection..........................................................

Table 2-4. Target frit compositions (in wt\% oxides) for the melter test glasses...................................................5

Table 2-5. Target glass compositions (in wt $\%$ oxides) at $35 \%$ waste loading......................................................6

Table 2-6. Target glass compositions (in wt $\%$ oxides) at $40 \%$ waste loading......................................................

Table 3-1. Visual observations and XRD results for the study glasses. ..........................................................9

Table 3-2. PCT results for the study glasses and standards, normalized to the target compositions...................11 


\section{LIST OF ABBREVIATIONS}

$\begin{array}{ll}\text { AD } & \text { Analytical Development } \\ \text { ARM } & \text { Approved Reference Material } \\ \text { CCC } & \text { canister centerline cooled } \\ \text { DOE } & \text { Department of Energy } \\ \text { DWPF } & \text { Defense Waste Processing Facility } \\ \text { EA } & \text { Environmental Assessment } \\ \text { EP-5 } & \text { Electricheskaya Pech - 5 (Electric Furnace - 5) } \\ \text { HLW } & \text { High Level Waste } \\ \text { ICP-AES } & \text { Inductively Coupled Plasma - Atomic Emission Spectroscopy } \\ \text { KRI } & \text { V.G. Khlopin Radium Institute } \\ \text { LWO } & \text { Liquid Waste Organization } \\ \text { MAR } & \text { Measurement Acceptability Region } \\ \text { NL } & \text { Normalized Leachate } \\ \text { PCT } & \text { Product Consistency Test } \\ \text { PNNL } & \text { Pacific Northwest National Laboratory } \\ \text { PSAL } & \text { Process Science Analytical Laboratory } \\ \text { SB5 } & \text { Sludge Batch 5 } \\ \text { SMK } & \text { Steklo Metallicheskie Konstruktsii (Glass Metal Structures) } \\ \text { SRNL } & \text { Savannah River National Laboratory } \\ \text { SRS } & \text { Savannah River Site } \\ \text { WL } & \text { Waste Loading } \\ \text { XRD } & \text { X-ray Diffraction }\end{array}$




\subsection{Introduction}

The U.S. Department of Energy (DOE) is currently processing (or planning to process) high-level waste (HLW) through Joule-heated melters at the Savannah River Site (SRS) and Hanford. The process combines the HLW sludge with a glass frit or mined mineral glass forming additives. The mixture is subsequently melted with the resulting molten glass being poured into stainless steel canisters to create the final waste form. In preparation for the qualification and receipt of each sludge batch, development and definition of various tank blending and/or washing strategies have been or will be initiated. The various strategies have been contemplated in an effort to meet critical site objectives or constraints which include tank volume space, transfer options, and settling issues. Although these objectives or constraints are critical, one must not lose sight of both process and product performance issues associated with the final waste form. The product performance issue relates to the durability of the glass waste form. Process related issues (e.g., liquidus temperature, viscosity, electrical conductivity, and melting rate considerations) ultimately dictate the efficiency and effectiveness of the melter operation.

Tank retrieval and blending strategies at both SRS and Hanford have identified high $\mathrm{Al}_{2} \mathrm{O}_{3}$ waste streams that are scheduled to be processed through their respective HLW vitrification facilities. For example, the Liquid Waste Organziation (LWO) at SRS provided compositional projections with $\mathrm{Al}_{2} \mathrm{O}_{3}$ concentrations of more than $30 \mathrm{wt} \%$ on a calcined oxide basis for the next sludge batch (Sludge Batch 5) to be processed in the Defense Waste Processing Facility (DWPF). ${ }^{1}$ In addition, physical limitations in the Tank Farms and/or settling issues associated with the sludge have prevented advanced washing which has resulted in relatively high $\mathrm{Na}_{2} \mathrm{O}$ (between 22 and $26 \mathrm{wt} \%$ ) and $\mathrm{SO}_{4}$ (between approximately 0.8 and $1.6 \mathrm{wt} \%$ ) concentrations for these projections. Current Hanford projections suggest the $\mathrm{Al}_{2} \mathrm{O}_{3}$ concentrations in sludge could be much greater than those currently projected for DWPF, with $\mathrm{Al}_{2} \mathrm{O}_{3}$ concentrations as high as $80 \mathrm{wt} \%$.

The overall objective of this study was to develop glass formulations for specific DOE waste streams to avoid the formation of nepheline (a crystalline phase that is apt to form in high $\mathrm{Al}_{2} \mathrm{O}_{3}$ concentration glasses and adversely affects the durability of the waste glass product) while maintaining or meeting waste loading (WL) and/or waste throughput expectations as well as satisfying critical process and product performance related constraints. ${ }^{2}$

The first portion of this study focused on development of a test matrix of glass compositions at both the Savannah River National Laboratory (SRNL) and the V.G. Khlopin Radium Institute (KRI) in Russia. These glass compositions were selected to evaluate the solubility of aluminum, chromium and sulfur over a range of compositions that were considered bounding for future sludge batches to be processed through the DWPF and Hanford. Development of the "US matrix" and "KRI matrix" of glass compositions is described in further detail elsewhere. ${ }^{3}$ An evaluation of the data resulting from analyses of these glasses is nearly complete at the time of this report. A statistical review of the resulting data has been issued by Edwards. ${ }^{4}$

The second portion of this study will focus on melter testing at KRI. Melter testing will occur in two stages. In the first stage, KRI's Steklo Metallicheskie Konstruktsii (SMK) melter will be used to evaluate several glass systems of interest for particular waste streams at SRS and Hanford. In the second stage, KRI's larger Electricheskaya Pech - 5 (EP-5) melter will be used to evaluate a reduced set of glasses based on the results of the SMK testing.

PNNL and SRNL will be responsible for identifying specific waste streams of interest to support melter testing at KRI. For SRNL (and in support of DWPF), that stream will be Sludge Batch 5 
(SB5) which is a high $\mathrm{Al}_{2} \mathrm{O}_{3}$ based sludge as currently projected. Two possible cases are under consideration for SB5 processing at SRS. One involves typical tank blending and washing strategies to produce a suitable feed for processing in the DWPF. The second involves an additional process where aluminum is dissolved and removed from the sludge in order to reduce the mass of material that must be processed through the DWPF. A final decision as to whether to implement the Aldissolution process has not been made at the time of this report, so SRNL will evaluate both of these cases for the SB5 waste stream.

The KRI, PNNL, and SRNL team will develop specific glass compositions to support the melter testing at KRI. Development of the specific glasses will be based in part on the results of the first portion of this study (i.e., the "US Matrix" and "KRI Matrix" glasses) and leverage existing data that may support the development process. Existing composition/property models will be used to support glass formulation efforts. The models will be a guide with respect to the acceptability of the specific glass composition relative to the acceptance criteria for Hanford and/or DWPF.

This report deals specifically with selection of the SRNL glass compositions to be run in the SMK melter tests. Glass compositions will be chosen using the two SB5 waste streams (with and without Al-dissolution) and frit compositions that are predicted to produce acceptable glass products with both waste streams. The glasses will be fabricated in the laboratory and select properties will be measured to ensure that critical acceptance criteria will be met. This can essentially be viewed as a risk reduction step to avoid making a larger quantity of glass in the melter that would ultimately be classified as unacceptable based on DWPF product or process specifications. Based on the results of this work, SRNL will identify six feeds to be tested in the SMK melter, three for the "SB5 without Al-dissolution" waste stream and three for the "SB5 with Al-dissolution" waste stream. The differences among these melter feeds will lie in the composition of the frit and the WL.

KRI will process the selected SRNL compositions through their SMK melter. Properties of the glasses, such as melt rate and chemical durability, will be evaluated. Based on these results, an additional down-selection process will be used to identify glass compositions to be tested in the KRI EP-5 melter at a later date. 


\subsection{Experimental Procedure}

This section describes the strategy used to select the glasses for the study, including the target sludge and frit compositions. The target glass compositions are then given, followed by a discussion of the techniques used to fabricate and analyze the glasses.

\subsection{Glass Selection Strategy}

Two sludge compositions, which correspond to variations of SB5, are of interest for this study. The first sludge composition was derived from the nominal SB5 composition projection issued in February $2007^{1}$ by re-normalizing without the radioactive elements. This sludge will be referred to as "SB5 without Al-dissolution". Its composition is given in Table 2-1. The second sludge will reflect the estimated impact of the aluminum dissolution process planned for SB5. This process will remove a portion of the aluminum in the sludge (to reduce the mass of sludge that must be processed through DWPF), which will in turn affect the re-normalized concentrations of most of the other components. The assumption will be made that $50 \%$ of the alumina is removed by the aluminum dissolution process. Also, it will be assumed that washing strategies will be employed to return the sludge to the same $\mathrm{Na}_{2} \mathrm{O}$ concentration after the aluminum dissolution process is completed. The $\mathrm{SO}_{4}{ }^{2-}$ concentration was allowed to re-normalize with the other components (i.e., washing impacts on the $\mathrm{SO}_{4}{ }^{2-}$ concentration were not considered). This second sludge composition is referred to as "SB5 with Al-dissolution," and its composition is given in Table 2-1.

Table 2-1. Target sludge compositions (in wt \% oxides) for the melter test glasses.

\begin{tabular}{||c|c|c||}
\hline Oxide & $\begin{array}{c}\text { SB5 w/o } \\
\text { Al-dissolution }\end{array}$ & $\begin{array}{c}\text { SB5 w/ } \\
\text { Al-dissolution }\end{array}$ \\
\hline $\mathrm{Al}_{2} \mathrm{O}_{3}$ & 33.246 & 16.623 \\
\hline $\mathrm{CaO}$ & 2.090 & 2.915 \\
\hline $\mathrm{Cr}_{2} \mathrm{O}_{3}$ & 0.200 & 0.279 \\
\hline $\mathrm{Fe}_{2} \mathrm{O}_{3}$ & 26.419 & 36.843 \\
\hline $\mathrm{K}_{2} \mathrm{O}$ & 0.160 & 0.223 \\
\hline $\mathrm{MnO}$ & 5.200 & 7.252 \\
\hline $\mathrm{Na}_{2} \mathrm{O}$ & 24.625 & 24.625 \\
\hline $\mathrm{NiO}$ & 2.310 & 3.221 \\
\hline $\mathrm{SiO} \mathrm{O}_{2}$ & 1.820 & 2.538 \\
\hline $\mathrm{TiO}_{2}$ & 0.520 & 0.725 \\
\hline $\mathrm{ZnO}$ & 0.070 & 0.098 \\
\hline $\mathrm{ZrO}_{2}$ & 0.230 & 0.321 \\
\hline $\mathrm{BaO}$ & 0.110 & 0.153 \\
\hline $\mathrm{Ce} \mathrm{O}_{3}$ & 0.230 & 0.321 \\
\hline $\mathrm{CuO}$ & 0.070 & 0.098 \\
\hline $\mathrm{La} \mathrm{O}_{3}$ & 0.030 & 0.042 \\
\hline $\mathrm{MgO}$ & 1.410 & 1.966 \\
\hline $\mathrm{PbO}$ & 0.100 & 0.139 \\
\hline $\mathrm{SO}_{4}{ }^{2-}$ & 1.160 & 1.618 \\
\hline $\mathrm{Total}$ & 100.000 & 100.000 \\
\hline
\end{tabular}

\footnotetext{
a The reader should keep in mind that these two sludge compositions are projections prior to the washing and blending strategies being finalized at SRS, and therefore they may not represent what is ultimately processed in DWPF for SB5. However, this testing will provide valuable insight into the effects of interest.
} 
A modeling evaluation was undertaken to select the frits to be combined with these two sludge compositions. The compositional array of interest for the frits was developed using four common components of frits used at DWPF $\left(\mathrm{B}_{2} \mathrm{O}_{3}, \mathrm{Na}_{2} \mathrm{O}, \mathrm{Li}_{2} \mathrm{O}\right.$ and $\mathrm{SiO}_{2}$ ), along with $\mathrm{CaO}$ (which may minimize nepheline crystallization in glasses with a high concentration of $\mathrm{Al}_{2} \mathrm{O}_{3}$ ). A range of concentrations for each of these components was chosen based on previous experience with DWPF processing, and is outlined in Table 2-2. Every combination of frit compositions described by this array was included in the paper study, for a total of 3003 individual frits.

Table 2-2. Ranges of frit component concentrations used in the paper study.

\begin{tabular}{|c|c|c|}
\hline Frit Component & Range (wt\%) & Increment (wt\%) \\
\hline $\mathrm{B}_{2} \mathrm{O}_{3}$ & $8-20$ & 1 \\
\hline $\mathrm{CaO}$ & $0-2$ & 1 \\
\hline $\mathrm{Li}_{2} \mathrm{O}$ & $5-11$ & 1 \\
\hline $\mathrm{Na}_{2} \mathrm{O}$ & $0-10$ & 1 \\
\hline $\mathrm{SiO}_{2}$ & $57-87$ & 1 \\
\hline
\end{tabular}

Measurement Acceptability Region (MAR) assessments were performed using the two sludge compositions, described earlier, along with this array of frit compositions. The sulfur solubility constraint was the only model that was not included in the assessment. ${ }^{a}$ The outcome of this process was a range of WLs over which the models predicted that an acceptable glass would be produced at DWPF for each combination of a single frit and a single sludge. The model or models that limited the achievable WL for each combination were also identified. Four frits were down-selected from these results based on their ability to provide a wide range of WLs where acceptable glasses were predicted for both sludge compositions. The paper study results for these four frits are summarized in Table 2-3. The limiting models include liquidus temperature $\left(\mathrm{T}_{\mathrm{L}}\right)$, crystallization of nepheline (Neph) and low viscosity (low $\eta$ ).

Table 2-3. Selected results of the paper study assessment for frit selection.

\begin{tabular}{|c|c|c|c|c|}
\hline \multirow{2}{*}{ Frit ID } & \multicolumn{2}{|c|}{ SB5 w/o Al-dissolution } & \multicolumn{2}{c|}{ SB5 w/ Al-dissolution } \\
\cline { 2 - 5 } & WL Range & Limiting Model & WL Range & Limiting Model \\
\hline 503 & $26-41$ & $\mathrm{~T}_{\mathrm{L}}$, Neph & $26-36$ & $\mathrm{~T}_{\mathrm{L}}$ \\
\hline 517 & $26-40$ & $\mathrm{Neph}$ & $26-28$ & low $\eta$ \\
\hline 520 & $25-42$ & $\mathrm{Neph}$ & $25-39$ & $\mathrm{~T}_{\mathrm{L}}$, low $\eta$ \\
\hline 521 & $25-40$ & $\mathrm{Neph}$ & $25-39$ & $\mathrm{~T}_{\mathrm{L}}$, low $\eta$ \\
\hline
\end{tabular}

In general, the ranges of WLs over which an acceptable glass is predicted were larger for the "SB5 without Al-dissolution" sludge composition. All of the selected frits provided WLs of $40 \%$ or better for this sludge. The WLs are all limited by predictions of nepheline crystallization. Frit 503 was also limited by a predicted liquidus temperature of more than $1050^{\circ} \mathrm{C}$ at a WL of $42 \%$.

The range of WLs over which an acceptable glass is predicted was smaller for the frits with the "SB5 with Al-dissolution" sludge composition. The WL ranges were limited by either predictions of high

\footnotetext{
${ }^{\mathrm{a}}$ The SB5 without Al-dissolution sludge composition (1.160 wt $\% \mathrm{SO}_{4}{ }^{2-}$ ) would become sulfate concentration limited at a waste loading of $52 \%$. The SB5 with Al-dissolution sludge composition (1.618 wt $\% \mathrm{SO}_{4}{ }^{2-}$ ) would become sulfate concentration limited at a waste loading of $37 \%$.
} 
liquidus temperature, low viscosity, or both. Frit 517 was limited to a WL range of only three percentage points. However, this frit has shown good melt rate results with the "SB5 without Aldissolution" sludge (which was attributed to its high $\mathrm{B}_{2} \mathrm{O}_{3}$ concentration) ${ }^{5}$ and was therefore included. The compositions of these four frits are listed in Table 2-4.

Table 2-4. Target frit compositions (in wt\% oxides) for the melter test glasses.

\begin{tabular}{||c|c|c|c|c|c|c||}
\hline Frit ID & $\mathbf{B}_{\mathbf{2}} \mathbf{O}_{3}$ & $\mathbf{C a O}$ & $\mathbf{L i}_{2} \mathbf{O}$ & $\mathbf{N a}_{\mathbf{2}} \mathbf{O}$ & $\mathbf{S i O}_{2}$ & Total \\
\hline 503 & 14 & 0 & 8 & 4 & 74 & 100 \\
\hline 517 & 17 & 0 & 10 & 3 & 70 & 100 \\
\hline 520 & 8 & 1 & 10 & 4 & 77 & 100 \\
\hline 521 & 10 & 1 & 8 & 6 & 75 & 100 \\
\hline
\end{tabular}

\subsection{Target Compositions of Selected Glasses}

To evaluate the impact of:

(a) frit composition on melt rate and/or nepheline crystallization for a specific waste stream, or

(b) waste stream differences for a fixed frit composition on melt rate and/or nepheline formation, or

(c) WL on melt rate and/or nepheline formation,

16 glasses were developed by combining one of each of the two sludge compositions with one of each of the four selected frit compositions. Two WLs were chosen for the test glasses: $35 \%$ (typical of current DWPF processing) and 40\% (to evaluate a potential increase in DWPF throughput). The glass compositions at 35\% WL are given in Table 2-5, and the glass compositions at $40 \% \mathrm{WL}$ are given in Table 2-6. 
Table 2-5. Target glass compositions (in wt $\%$ oxides) at $35 \%$ waste loading.

\begin{tabular}{|c|c|c|c|c|c|c|c|c|}
\hline Glass ID & RM-01 & RM-02 & RM-03 & RM-04 & RM-05 & RM-06 & RM-07 & RM-08 \\
\hline Frit & 520 & 503 & 517 & 521 & 520 & 503 & 517 & 521 \\
\hline $\begin{array}{l}\text { Sludge } \\
\text { Type }\end{array}$ & $\begin{array}{l}\text { SB5 w/o } \\
\text { Al-diss. }\end{array}$ & $\begin{array}{l}\text { SB5 w/o } \\
\text { Al-diss. }\end{array}$ & $\begin{array}{l}\text { SB5 w/o } \\
\text { Al-diss. }\end{array}$ & $\begin{array}{l}\text { SB5 w/o } \\
\text { Al-diss. }\end{array}$ & $\begin{array}{l}\text { SB5 w/ } \\
\text { Al-diss. }\end{array}$ & $\begin{array}{l}\text { SB5 w/ } \\
\text { Al-diss. }\end{array}$ & $\begin{array}{l}\text { SB5 w/ } \\
\text { Al-diss. }\end{array}$ & $\begin{array}{l}\text { SB5 w/ } \\
\text { Al-diss. }\end{array}$ \\
\hline $\mathrm{Al}_{2} \mathrm{O}_{3}$ & 11.64 & 11.64 & 11.64 & 11.64 & 5.82 & 5.82 & 5.82 & 5.82 \\
\hline $\mathrm{B}_{2} \mathrm{O}_{3}$ & 5.20 & 9.10 & 11.05 & 6.50 & 5.20 & 9.10 & 11.05 & 6.50 \\
\hline $\mathrm{CaO}$ & 1.38 & 0.73 & 0.73 & 1.38 & 1.67 & 1.02 & 1.02 & 1.67 \\
\hline $\mathrm{Cr}_{2} \mathrm{O}_{3}$ & 0.07 & 0.07 & 0.07 & 0.07 & 0.10 & 0.10 & 0.10 & 0.10 \\
\hline $\mathrm{Fe}_{2} \mathrm{O}_{3}$ & 9.25 & 9.25 & 9.25 & 9.25 & 12.90 & 12.90 & 12.90 & 12.90 \\
\hline $\mathrm{K}_{2} \mathrm{O}$ & 0.06 & 0.06 & 0.06 & 0.06 & 0.08 & 0.08 & 0.08 & 0.08 \\
\hline $\mathrm{Li}_{2} \mathrm{O}$ & 6.50 & 5.20 & 6.50 & 5.20 & 6.50 & 5.20 & 6.50 & 5.20 \\
\hline $\mathrm{MnO}$ & 1.82 & 1.82 & 1.82 & 1.82 & 2.54 & 2.54 & 2.54 & 2.54 \\
\hline $\mathrm{Na}_{2} \mathrm{O}$ & 11.22 & 11.22 & 10.57 & 12.52 & 11.22 & 11.22 & 10.57 & 12.52 \\
\hline $\mathrm{NiO}$ & 0.81 & 0.81 & 0.81 & 0.81 & 1.13 & 1.13 & 1.13 & 1.13 \\
\hline $\mathrm{SiO}_{2}$ & 50.69 & 48.74 & 46.14 & 49.39 & 50.94 & 48.99 & 46.39 & 49.64 \\
\hline $\mathrm{TiO}_{2}$ & 0.18 & 0.18 & 0.18 & 0.18 & 0.25 & 0.25 & 0.25 & 0.25 \\
\hline $\mathrm{ZnO}$ & 0.02 & 0.02 & 0.02 & 0.02 & 0.03 & 0.03 & 0.03 & 0.03 \\
\hline $\mathrm{ZrO}_{2}$ & 0.08 & 0.08 & 0.08 & 0.08 & 0.11 & 0.11 & 0.11 & 0.11 \\
\hline $\mathrm{BaO}$ & 0.04 & 0.04 & 0.04 & 0.04 & 0.05 & 0.05 & 0.05 & 0.05 \\
\hline $\mathrm{Ce}_{2} \mathrm{O}_{3}$ & 0.08 & 0.08 & 0.08 & 0.08 & 0.11 & 0.11 & 0.11 & 0.11 \\
\hline $\mathrm{CuO}$ & 0.02 & 0.02 & 0.02 & 0.02 & 0.03 & 0.03 & 0.03 & 0.03 \\
\hline $\mathrm{La}_{2} \mathrm{O}_{3}$ & 0.01 & 0.01 & 0.01 & 0.01 & 0.01 & 0.01 & 0.01 & 0.01 \\
\hline $\mathrm{MgO}$ & 0.49 & 0.49 & 0.49 & 0.49 & 0.69 & 0.69 & 0.69 & 0.69 \\
\hline $\mathrm{PbO}$ & 0.04 & 0.04 & 0.04 & 0.04 & 0.05 & 0.05 & 0.05 & 0.05 \\
\hline $\mathrm{SO}_{4}{ }^{2-}$ & 0.41 & 0.41 & 0.41 & 0.41 & 0.57 & 0.57 & 0.57 & 0.57 \\
\hline Total & 100.00 & 100.00 & 100.00 & 100.00 & 100.00 & 100.00 & 100.00 & 100.00 \\
\hline
\end{tabular}


Table 2-6. Target glass compositions (in wt\% oxides) at $40 \%$ waste loading.

\begin{tabular}{|c|c|c|c|c|c|c|c|c|}
\hline Glass ID & RM-09 & RM-10 & RM-11 & RM-12 & RM-13 & RM-14 & RM-15 & RM-16 \\
\hline Frit ID & 520 & 503 & 517 & 521 & 520 & 503 & 517 & 521 \\
\hline $\begin{array}{l}\text { Sludge } \\
\text { Type }\end{array}$ & $\begin{array}{l}\text { SB5 w/o } \\
\text { Al-diss. }\end{array}$ & $\begin{array}{l}\text { SB5 w/o } \\
\text { Al-diss. }\end{array}$ & $\begin{array}{l}\text { SB5 w/o } \\
\text { Al-diss. }\end{array}$ & $\begin{array}{l}\text { SB5 w/o } \\
\text { Al-diss. }\end{array}$ & $\begin{array}{l}\text { SB5 w/ } \\
\text { Al-diss. }\end{array}$ & $\begin{array}{l}\text { SB5 w/ } \\
\text { Al-diss. }\end{array}$ & $\begin{array}{l}\text { SB5 w/ } \\
\text { Al-diss. }\end{array}$ & $\begin{array}{l}\text { SB5 w/ } \\
\text { Al-diss. }\end{array}$ \\
\hline $\mathrm{Al}_{2} \mathrm{O}_{3}$ & 13.30 & 13.30 & 13.30 & 13.30 & 6.65 & 6.65 & 6.65 & 6.65 \\
\hline $\mathrm{B}_{2} \mathrm{O}_{3}$ & 4.80 & 8.40 & 10.20 & 6.00 & 4.80 & 8.40 & 10.20 & 6.00 \\
\hline $\mathrm{CaO}$ & 1.44 & 0.84 & 0.84 & 1.44 & 1.77 & 1.17 & 1.17 & 1.77 \\
\hline $\mathrm{Cr}_{2} \mathrm{O}_{3}$ & 0.08 & 0.08 & 0.08 & 0.08 & 0.11 & 0.11 & 0.11 & 0.11 \\
\hline $\mathrm{Fe}_{2} \mathrm{O}_{3}$ & 10.57 & 10.57 & 10.57 & 10.57 & 14.74 & 14.74 & 14.74 & 14.74 \\
\hline $\mathrm{K}_{2} \mathrm{O}$ & 0.06 & 0.06 & 0.06 & 0.06 & 0.09 & 0.09 & 0.09 & 0.09 \\
\hline $\mathrm{Li}_{2} \mathrm{O}$ & 6.00 & 4.80 & 6.00 & 4.80 & 6.00 & 4.80 & 6.00 & 4.80 \\
\hline $\mathrm{MnO}$ & 2.08 & 2.08 & 2.08 & 2.08 & 2.90 & 2.90 & 2.90 & 2.90 \\
\hline $\mathrm{Na}_{2} \mathrm{O}$ & 12.25 & 12.25 & 11.65 & 13.45 & 12.25 & 12.25 & 11.65 & 13.45 \\
\hline $\mathrm{NiO}$ & 0.92 & 0.92 & 0.92 & 0.92 & 1.29 & 1.29 & 1.29 & 1.29 \\
\hline $\mathrm{SiO}_{2}$ & 46.93 & 45.13 & 42.73 & 45.73 & 47.22 & 45.42 & 43.02 & 46.02 \\
\hline $\mathrm{TiO}_{2}$ & 0.21 & 0.21 & 0.21 & 0.21 & 0.29 & 0.29 & 0.29 & 0.29 \\
\hline $\mathrm{ZnO}$ & 0.03 & 0.03 & 0.03 & 0.03 & 0.04 & 0.04 & 0.04 & 0.04 \\
\hline $\mathrm{ZrO}_{2}$ & 0.09 & 0.09 & 0.09 & 0.09 & 0.13 & 0.13 & 0.13 & 0.13 \\
\hline $\mathrm{BaO}$ & 0.04 & 0.04 & 0.04 & 0.04 & 0.06 & 0.06 & 0.06 & 0.06 \\
\hline $\mathrm{Ce}_{2} \mathrm{O}_{3}$ & 0.09 & 0.09 & 0.09 & 0.09 & 0.13 & 0.13 & 0.13 & 0.13 \\
\hline $\mathrm{CuO}$ & 0.03 & 0.03 & 0.03 & 0.03 & 0.04 & 0.04 & 0.04 & 0.04 \\
\hline $\mathrm{La}_{2} \mathrm{O}_{3}$ & 0.01 & 0.01 & 0.01 & 0.01 & 0.02 & 0.02 & 0.02 & 0.02 \\
\hline $\mathrm{MgO}$ & 0.56 & 0.56 & 0.56 & 0.56 & 0.79 & 0.79 & 0.79 & 0.79 \\
\hline $\mathrm{PbO}$ & 0.04 & 0.04 & 0.04 & 0.04 & 0.06 & 0.06 & 0.06 & 0.06 \\
\hline $\mathrm{SO}_{4}{ }^{2-}$ & 0.46 & 0.46 & 0.46 & 0.46 & 0.65 & 0.65 & 0.65 & 0.65 \\
\hline Total & 100.00 & 100.00 & 100.00 & 100.00 & 100.00 & 100.00 & 100.00 & 100.00 \\
\hline
\end{tabular}

\subsection{Glass Fabrication}

Each study glass was prepared from the proper proportions of reagent-grade metal oxides, carbonates, $\mathrm{H}_{3} \mathrm{BO}_{3}$, and salts in $150 \mathrm{~g}$ batches. ${ }^{6}$ The raw materials were thoroughly mixed and placed into a $95 \%$ platinum / 5\% gold, $250 \mathrm{ml}$ crucible. The batch was placed into a high-temperature furnace at the target melt temperature of $1150^{\circ} \mathrm{C}^{7}$ The crucible was removed from the furnace after an isothermal hold at $1150^{\circ} \mathrm{C}$ for 1 hour. The glass was poured onto a clean, stainless steel plate and allowed to air cool (quench). The glass pour patty was used as a sampling stock for the various property measurements, including chemical composition and durability testing.

Approximately $25 \mathrm{~g}$ of each glass was heat-treated to simulate cooling along the centerline of a DWPF-type canister ${ }^{8}$ to gauge the effects of thermal history on the product performance. This cooling schedule is referred to as the CCC curve. Visual observations on both quenched and CCC glasses were recorded. 


\subsection{Property Measurements}

This section provides a general discussion of the durability and crystallization analyses of the melter test glasses.

\subsubsection{Product Consistency Test}

The Product Consistency Test (PCT) ${ }^{9}$ was performed in triplicate on each quenched and CCC glass to assess chemical durability. Also included in the experimental test matrix was the Environmental Assessment (EA) glass, ${ }^{10}$ the Approved Reference Material (ARM) glass, and blanks from the sample cleaning batch. Samples were ground, washed, and prepared according to the standard procedure. ${ }^{9}$ Fifteen milliliters of Type I ASTM water were added to $1.5 \mathrm{~g}$ of glass in stainless steel vessels. The vessels were closed, sealed, and placed in an oven at $90 \pm 2{ }^{\circ} \mathrm{C}$ where the samples were maintained at temperature for 7 days. Once cooled, the resulting solutions were sampled (filtered and acidified), then labeled and analyzed by the Process Science Analytical Laboratory (PSAL) using inductively coupled plasma - atomic emission spectroscopy (ICP-AES). Normalized release rates were calculated based on target compositions using the average of the common logarithms of the leachate concentrations.

\subsubsection{X-Ray Diffraction Analysis}

Although visual observations for crystallization were performed and documented, representative samples for all quenched and CCC glasses were submitted to SRNL Analytical Development (AD) for X-ray diffraction (XRD) analysis. Samples were analyzed under conditions providing a detection limit of approximately $0.5 \mathrm{vol} \%$. That is, if a crystalline phase were present at $0.5 \mathrm{vol} \%$ or greater, the diffractometer would not only be capable of detecting the crystals but would also allow a qualitative determination of the type of crystal(s) present. Otherwise, a characteristically high background devoid of crystalline spectral peaks indicates that the glass product is amorphous, suggesting either a completely amorphous product or that the degree of crystallization is below the detection limit. 


\subsection{Results and Discussion}

The following subsections describe the chemical and physical property measurements performed on each test glass.

\subsection{Homogeneity}

Table 3-1 lists the visual and XRD results for the quenched and CCC versions of the variability study glasses. These results will be summarized below.

Table 3-1. Visual observations and XRD results for the study glasses.

\begin{tabular}{|c|c|c|c|}
\hline Glass ID & "Heat Treatment & Visual Observations & XRD Results \\
\hline \multirow{2}{*}{ RM-01 } & quenched & clean, black and shiny & amorphous \\
\hline & CCC & surface: dull; bulk: clean and shiny & trevorite \\
\hline \multirow{2}{*}{ RM-02 } & quenched & clean, black and shiny & magnetite \\
\hline & $\mathrm{CCC}$ & surface: dull, a few crystals; bulk: clean and shiny & trevorite \\
\hline \multirow{2}{*}{ RM-03 } & quenched & clean, black and shiny & amorphous \\
\hline & CCC & surface: dull, a few crystals; bulk: clean and shiny & amorphous \\
\hline \multirow{2}{*}{ RM-04 } & quenched & clean, black and shiny & amorphous \\
\hline & CCC & surface: dull; bulk: clean and shiny & amorphous \\
\hline \multirow{2}{*}{ RM-05 } & quenched & clean, black and shiny & amorphous \\
\hline & CCC & surface: dull, many crystals; bulk: clean and shiny & possible trevorite \\
\hline \multirow{2}{*}{ RM-06 } & quenched & clean, black and shiny & amorphous \\
\hline & CCC & surface: dull, a few crystals; bulk: clean and shiny & amorphous \\
\hline \multirow{2}{*}{ RM-07 } & quenched & clean, black and shiny & magnetite \\
\hline & CCC & surface: dull, very few crystals; bulk: clean and shiny & trevorite \\
\hline \multirow{2}{*}{ RM-08 } & quenched & clean, black and shiny & amorphous \\
\hline & CCC & surface: dull, many crystals; bulk: clean and shiny & amorphous \\
\hline \multirow{2}{*}{ RM-09 } & quenched & clean, black and shiny & magnetite \\
\hline & CCC & surface: dull; bulk: clean and shiny & trevorite \\
\hline \multirow{2}{*}{ RM-10 } & quenched & clean, black and shiny & possible magnetite \\
\hline & CCC & surface: dull, very few crystals; bulk: clean and shiny & trevorite \\
\hline \multirow{2}{*}{ RM-11 } & quenched & clean, black and shiny & magnetite, hematite \\
\hline & CCC & surface: dull; bulk: clean and shiny & trevorite \\
\hline \multirow{2}{*}{ RM-12 } & quenched & clean, black and shiny & amorphous \\
\hline & CCC & surface: dull; bulk: clean and shiny & trevorite \\
\hline \multirow{2}{*}{ RM-13 } & quenched & black and shiny, hazy strip on surface & amorphous \\
\hline & CCC & surface: dull, a few crystals; bulk: clean and shiny & trevorite \\
\hline \multirow[b]{2}{*}{ RM-14 } & quenched & clean, black and shiny & amorphous \\
\hline & CCC & $\begin{array}{l}\text { surface: dull, one small group of crystals; bulk: clean } \\
\text { and shiny }\end{array}$ & trevorite \\
\hline \multirow{2}{*}{ RM-15 } & quenched & clean, black and shiny & possible magnetite \\
\hline & CCC & surface: dull; bulk: clean and shiny & trevorite \\
\hline \multirow[b]{2}{*}{ RM-16 } & quenched & clean, black and shiny & possible magnetite \\
\hline & CCC & $\begin{array}{l}\text { surface: dull, one small group of crystals; bulk: clean } \\
\text { and shiny }\end{array}$ & trevorite \\
\hline
\end{tabular}

\subsubsection{Visual Observations}

Prior to discussing the visual observations, a few words regarding the terminology used are warranted. The term "surface" refers to the surface of the quenched pour patty or glass sample after the CCC 
heat treatment. The term "bulk" refers to the cross-section of the quenched pour patty or glass sample after the CCC heat treatment. The use of "clean" or "shiny" indicates that the sample was classified as homogeneous and amorphous (i.e., no visible evidence of crystallization).

Visual observations of the quenched glasses indicate that all of the glasses were homogeneous. Surface crystallization was present on all of the CCC glasses. A "dull” surface is indicative of crystallization. In some cases, individual clusters of crystals were visible on the surface of the CCC glasses as well. The cross-sections of the CCC glasses were all free of crystallization by visual observation.

\subsubsection{XRD Results}

The XRD results are given in Table 3-1 and provide qualitative results regarding crystallization in the study glasses. The full XRD spectra for each of the glasses, both quenched and CCC, are included in the appendix. Note that some of the XRD spectra in the appendix contain an unidentified phase indicated by question marks. This phase was attributed to minor contamination from the tungsten carbide grinder used to prepare powder samples for XRD analysis. This contamination had no effect on the outcome of the study. Also note that in some cases, crystallization was detected by XRD where none was visually observed. This results from the very low detection limit $(0.5 \mathrm{vol} \%$ crystallization) achievable by XRD.

In general, all of the quenched glasses (both 35 and 40\% WL) were either X-ray amorphous (no crystallization at the XRD detection limit) or contained small amounts of magnetite and/or trevorite (spinel). XRD results for the CCC glasses were similar to those for the quenched glasses, although all of the CCC glasses at 40\% WL (glasses RM-09 through RM-16) were found to contain trevorite. Spinels are a common crystalline phase found in DWPF glasses and typically result from higher WLs and/or slow cooling cycles (the CCC heat treatment). Spinels have been shown to have little impact on the durability of the glass ${ }^{11}$ and therefore should not impact the outcome of this study. The results of the PCTs, discussed below, will verify whether or not these crystalline phases had a significant impact on durability of the glasses. It is noted that nepheline formation was not identified in any of the study glasses up to $40 \% \mathrm{WL}$, consistent with the nepheline discriminator constraint that was included in the paper study assessments.

\subsection{Durability}

The PCT was completed for each of the 16 test glasses, both quenched and CCC. The ARM and EA standard glasses were also included in the tests. The results of the PCTs, normalized to the target glass compositions, are given in Table 3-2. 
Table 3-2. PCT results for the study glasses and standards, normalized to the target compositions.

\begin{tabular}{|c|c|c|c|c|c|c|c|c|}
\hline $\begin{array}{l}\text { Glass } \\
\text { ID }\end{array}$ & $\begin{array}{l}\text { Frit } \\
\text { ID }\end{array}$ & $\begin{array}{l}\text { Sludge } \\
\text { Type }\end{array}$ & WL & $\begin{array}{c}\text { Heat } \\
\text { Treatment }\end{array}$ & $\begin{array}{c}\text { NL [Li] } \\
(\mathrm{g} / \mathrm{L})\end{array}$ & $\begin{array}{c}\text { NL [B] } \\
(\mathrm{g} / \mathrm{L})\end{array}$ & $\begin{array}{c}\text { NL [Na] } \\
(\mathrm{g} / \mathrm{L})\end{array}$ & $\begin{array}{c}\text { NL [Si] } \\
(\mathrm{g} / \mathrm{L})\end{array}$ \\
\hline ARM & - & - & - & - & 0.57 & 0.51 & 0.51 & 0.28 \\
\hline EA & - & - & - & - & 9.82 & 18.52 & 14.25 & 4.03 \\
\hline \multirow{2}{*}{ RM-01 } & \multirow{2}{*}{520} & \multirow{8}{*}{ 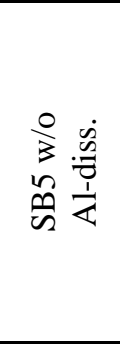 } & \multirow{16}{*}{$35 \%$} & quenched & 0.63 & 0.56 & 0.57 & 0.40 \\
\hline & & & & CCC & 0.62 & 0.53 & 0.57 & 0.39 \\
\hline \multirow{2}{*}{ RM-02 } & \multirow{2}{*}{503} & & & quenched & 0.60 & 0.50 & 0.46 & 0.39 \\
\hline & & & & $\mathrm{CCC}$ & 0.59 & 0.50 & 0.48 & 0.38 \\
\hline \multirow{2}{*}{ RM-03 } & \multirow{2}{*}{517} & & & quenched & 0.66 & 0.60 & 0.55 & 0.43 \\
\hline & & & & CCC & 0.64 & 0.59 & 0.59 & 0.42 \\
\hline \multirow{2}{*}{ RM-04 } & \multirow{2}{*}{521} & & & quenched & 0.59 & 0.50 & 0.60 & 0.38 \\
\hline & & & & CCC & 0.58 & 0.48 & 0.57 & 0.37 \\
\hline \multirow{2}{*}{ RM-05 } & \multirow{2}{*}{520} & \multirow{8}{*}{ 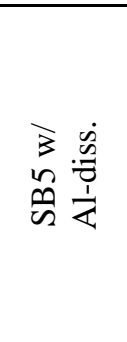 } & & quenched & 0.96 & 1.05 & 1.01 & 0.59 \\
\hline & & & & CCC & 1.06 & 1.03 & 1.01 & 0.63 \\
\hline \multirow{2}{*}{ RM-06 } & \multirow{2}{*}{503} & & & quenched & 0.75 & 0.74 & 0.70 & 0.45 \\
\hline & & & & CCC & 0.77 & 0.77 & 0.76 & 0.47 \\
\hline \multirow{2}{*}{ RM-07 } & \multirow{2}{*}{517} & & & quenched & 0.95 & 0.99 & 0.92 & 0.53 \\
\hline & & & & CCC & 0.92 & 0.96 & 0.90 & 0.54 \\
\hline \multirow{2}{*}{ RM-08 } & \multirow{2}{*}{521} & & & quenched & 0.86 & 0.86 & 0.96 & 0.53 \\
\hline & & & & CCC & 0.87 & 0.86 & 0.93 & 0.53 \\
\hline \multirow{2}{*}{ RM-09 } & \multirow{2}{*}{520} & \multirow{8}{*}{ 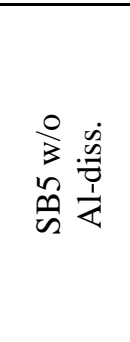 } & \multirow{16}{*}{$40 \%$} & quenched & 0.67 & 0.60 & 0.69 & 0.42 \\
\hline & & & & CCC & 1.14 & 1.02 & 0.85 & 0.55 \\
\hline \multirow{2}{*}{ RM-10 } & \multirow{2}{*}{503} & & & quenched & 0.65 & 0.55 & 0.57 & 0.40 \\
\hline & & & & CCC & 0.62 & 0.52 & 0.56 & 0.39 \\
\hline \multirow{2}{*}{ RM-11 } & \multirow{2}{*}{517} & & & quenched & 0.66 & 0.69 & 0.62 & 0.43 \\
\hline & & & & CCC & 0.66 & 0.66 & 0.60 & 0.43 \\
\hline RM-12 & 521 & & & quenched & 0.58 & 0.56 & 0.64 & 0.38 \\
\hline RIVI-IL & 521 & & & CCC & 1.19 & 1.32 & 0.92 & 0.51 \\
\hline $\mathrm{PM}-12$ & 520 & & & quenched & 1.02 & 1.13 & 1.21 & 0.62 \\
\hline RIVI-13 & 520 & & & CCC & 1.16 & 1.15 & 1.20 & 0.67 \\
\hline & & & & quenched & 0.80 & 0.85 & 0.88 & 0.48 \\
\hline RM-14 & 503 & $\overline{3} \dot{n}$ & & CCC & 0.82 & 0.86 & 0.87 & 0.49 \\
\hline RM-15 & 517 & $0 \frac{1}{1}$ & & quenched & 1.01 & 1.13 & 1.11 & 0.56 \\
\hline RIVI-IS & $51 /$ & & & CCC & 1.10 & 1.18 & 1.15 & 0.61 \\
\hline & 521 & & & quenched & 0.92 & 1.03 & 1.15 & 0.56 \\
\hline RIM-16 & 521 & & & CCC & 0.97 & 1.05 & 1.14 & 0.58 \\
\hline
\end{tabular}

The measured values for the ARM glass fall within the specified control limits. ${ }^{12}$ Note that the normalized release for boron for the EA glass is slightly above the typical value of $16.695 \mathrm{~g} / \mathrm{L} .{ }^{10}$

The PCT results for the 16 study glasses show that each glass has a durability that is considered very acceptable, with normalized releases for boron (NL [B] in g/L) that are better than an order of magnitude below that of the EA glass standard, regardless of heat treatment. There is little difference between the PCT responses of the quenched and CCC versions for most of the glasses, indicating that the small amount of crystallization identified in the CCC glasses by visual observation and XRD has no measurable impact on durability. The exceptions to this are glasses RM-09 and RM-12. The NL $[\mathrm{B}]$ values for the CCC versions of these glasses are approximately double the values for the 
quenched versions. However, the NL [B] values for the CCC versions of these glasses are still well below that of the EA glass benchmark. In terms of durability, any of the four frits tested would produce an acceptable glass with the sludge compositions used. 
WSRC-STI-2007-00363

Revision 0

\subsection{Discussion and Conclusions}

Four frits were developed for possible use in melter testing with KRI's SMK melter. The frits were selected using MAR assessments of an array of frit formulations and two SB5 flowsheets, one with the anticipated compositional effect of the implementation of Al-dissolution and one without. Test glasses were fabricated in the laboratory to verify that the durability and nepheline crystallization models used to select the frits were applicable to the frit/sludge systems of interest.

Each of the four frits was tested with each of the two sludges at two different waste loadings, for a total of 16 test glasses. Each glass was both quenched and subjected to the CCC thermal profile. Samples of each glass were examined for crystallization by XRD and durability using the PCT. The quenched version of each glass appeared amorphous by visual observations, although XRD results indicated a small amount of crystallization in four of the quenched glasses. Visual observations identified surface crystallization on the CCC versions of all 16 glasses. Three of the 35\% WL CCC glasses were found to contain trevorite (a spinel) by XRD, and all of the $40 \%$ WL CCC glasses were found to contain trevorite.

In terms of durability, any of the four frits tested would produce an acceptable glass with the sludge compositions used. The PCT results for the study glasses showed that each glass has a durability that is considered very acceptable, with normalized releases for boron that are better than an order of magnitude below that of the EA glass standard. Only two of the study glasses showed measurable differences in PCT response between the quenched and CCC heat treatments.

Overall, there was little difference in the performance of the four frits across the SB5 compositions and waste loadings tested. Each frit tended to provide good results (in terms of crystallization and durability) for some combinations of sludge composition and waste loading, while not performing as well as some of the other frits for other combinations. Note however that all of the frits performed very well with respect to forming an acceptable glass, with either a small amount or no crystallization detectable by XRD and PCT responses that were an order of magnitude better than the EA glass benchmark. As an example, glasses produced with Frit 521 at 35\% waste loading with and without Al-dissolution contained no crystallization in either the quenched or CCC forms and had excellent durabilities. However, at $40 \%$ waste loading with the non-Al-dissolution sludge, the glass formulated with Frit 521 showed a measurable difference in PCT response between the quenched and CCC versions.

Because it was difficult to identify the better performing frits based on these crystallization and PCT data, the selection was made with the intent of better determining the effect of frit composition on melt rate. Recent frit development efforts for DWPF have identified frits with a higher concentration of $\mathrm{B}_{2} \mathrm{O}_{3}$ as being beneficial for improving melt rate. ${ }^{13}$ Frits 520, 503 and 517 are therefore recommended for the SMK melter testing because they cover a relatively wide range of $\mathrm{B}_{2} \mathrm{O}_{3}$ concentrations (8, 14 and $17 \mathrm{wt} \%$, respectively). This selection of frits also eliminates the frit that resulted in the poorest normalized release for boron seen in this study (1.32 g/L for Frit 521 at $40 \%$ WL with the "SB5 without Al-dissolution" sludge). 
WSRC-STI-2007-00363

Revision 0

This page intentionally left blank. 


\subsection{Recommendations}

- It is recommended that KRI utilize Frits 503, 517 and 520 for testing of the SRNL sludges (SB5 with and without Al-dissolution) in the SMK melter.

- Each frit should be tested with each of the two SB5 flowsheets at a waste loading of 35\%, for a total of six tests in the SMK melter.

- The results of the SMK melter testing should be used to down-select a smaller number of frits or a single frit at multiple waste loadings for testing in the EP-5 melter. 
WSRC-STI-2007-00363

Revision 0

This page intentionally left blank. 
WSRC-STI-2007-00363

Revision 0

\subsection{References}

1. Shah, H. B., "Estimate of Sludge Batch 4 and 5 Sludge Calcine Compositions for SRNL," U.S. Department of Energy Report LWO-PIT-2007-00017, Washington Savannah River Company, Aiken, SC (2007).

2. Peeler, D. K. and T. B. Edwards, "Test Plan: Improved Alumina Solubility in US High Level Waste Glasses,” U.S. Department of Energy Report SRNL-PSE-2006-00275, Washington Savannah River Company, Aiken, SC 2006).

3. Aloy, A., J. D. Vienna, K. M. Fox, T. B. Edwards and D. K. Peeler, "Glass Selection Strategy: Development of US and KRI Test Matrices,” U.S. Department of Energy Report WSRC-STI-200600205, Revision 0, Washington Savannnah River Company, Aiken, SC (2006).

4. Edwards, T. B., "A Statistical Review of the Chemical Composition Measurements and PCT Results for the Glass Fabricated as Part of the US Test Matrix," U.S. Department of Energy Report SRNL-SCS-2007-00029, Washington Savannah River Company, Aiken, SC (2007).

5. Fox, K. M., T. B. Edwards, D. R. Best, I. A. Reamer and R. J. Workman, "Selection and Characterization of Preliminary Frits for High Level Waste Sludge Batch 5,” U.S. Department of Energy Report WSRC-STI-2007-00418, Washington Savannah River Company, Aiken, SC (2007).

6. SRNL, “Glass Batching,” SRTC Procedure Manual, L29, ITS-0001, Westinghouse Savannah River Company, Aiken, SC (2002).

7. SRNL, “Glass Melting," SRTC Procedure Manual, L29, ITS-0003, Westinghouse Savannah River Company, Aiken, SC (2002).

8. Marra, S. L. and C. M. Jantzen, "Characterization of Projected DWPF Glass Heat Treated to Simulate Canister Centerline Cooling,” U.S. Department of Energy Report WSRC-TR-92-142, Revision 1, Westinghouse Savannah River Company, Aiken, SC (1993).

9. ASTM, "Standard Test Methods for Determining Chemical Durability of Nuclear Waste Glasses: The Product Consistency Test (PCT),” ASTM C-1285, (2002).

10. Jantzen, C. M., N. E. Bibler, D. C. Beam, C. L. Crawford and M. A. Pickett, "Characterization of the Defense Waste Processing Facility (DWPF) Environmental Assessment (EA) Glass Standard Reference Material," U.S. Department of Energy Report WSRC-TR-92-346, Revision 1, Westinghouse Savannah River Company, Aiken, SC (1993).

11. Bickford, D. F. and C. M. Jantzen, "Devitrification of SRL Defense Waste Glass," Sci. Basis for Nuclear Waste Management VII, edited by G. L. McVay. Elsevier, New York, pp. 557-565 (1984).

12. Jantzen, C. M., J. B. Picket, K. G. Brown, T. B. Edwards and D. C. Beam, "Process/Product Models for the Defense Waste Processing Facility (DWPF): Part I. Predicting Glass Durability from Composition Using a Thermodynamic Hydration Energy Reaction Model (THERMO)," U.S. Department of Energy Report WSRC-TR-93-672, Revision 1, Westinghouse Savannah River Company, Aiken, SC (1995). 
WSRC-STI-2007-00363

Revision 0

13. Peeler, D. K. and T. B. Edwards, "High $\mathrm{B}_{2} \mathrm{O}_{3} / \mathrm{Fe}_{2} \mathrm{O}_{3}$-based Frits: MAR Assessments for Sludge Batch 4 (SB4),” U.S. Department of Energy Report WSRC-TR-2006-00181, Revision 0, Washington Savannah River Company, Aiken, SC (2006). 


\subsection{Appendix}

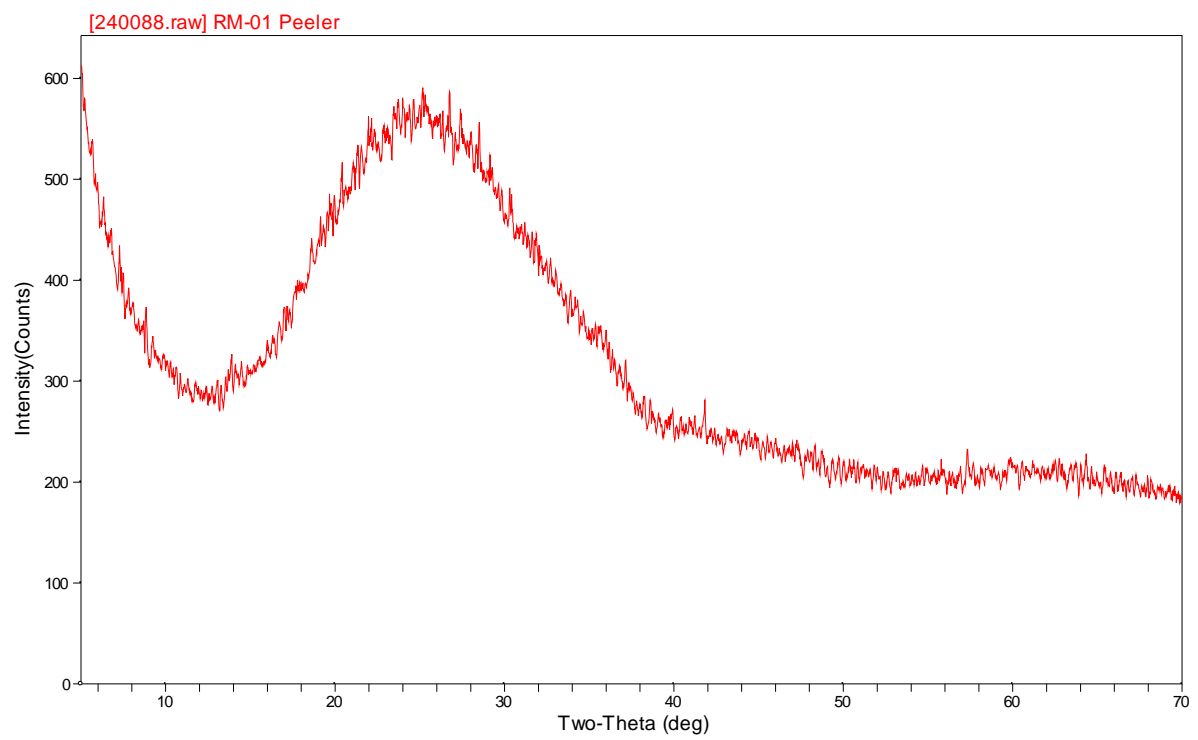

Figure A-1. XRD results for quenched glass RM-01.

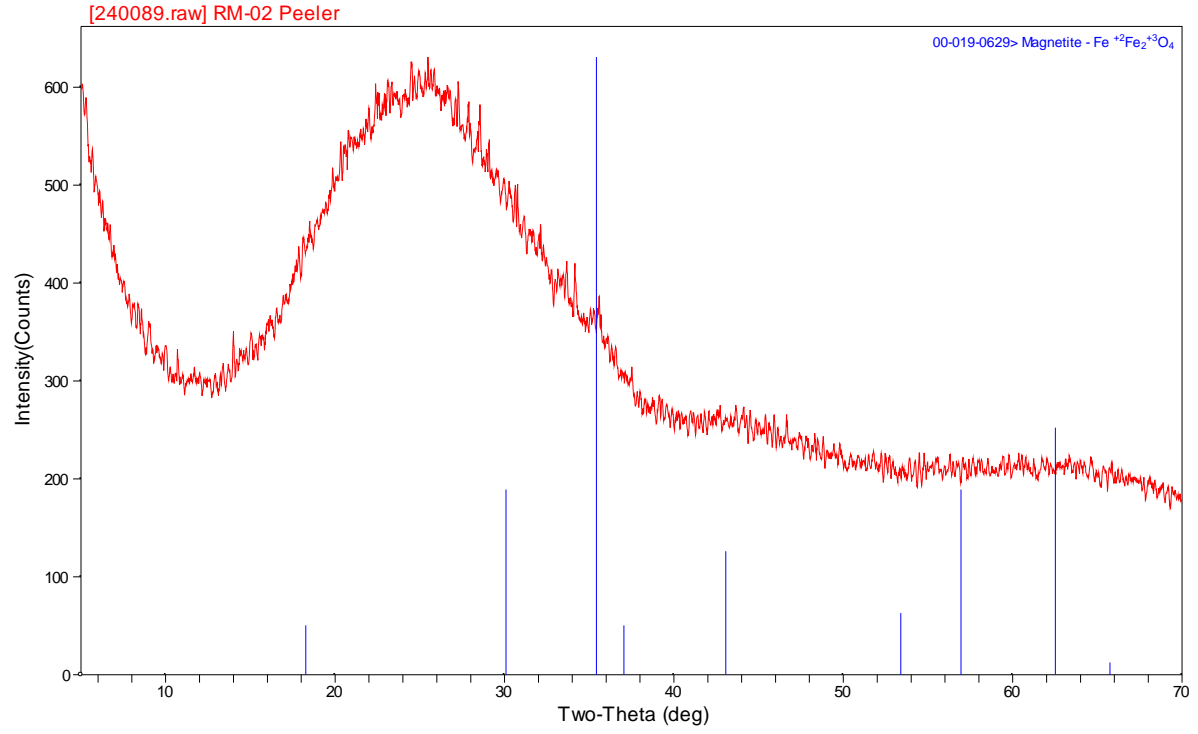

Figure A-2. XRD results for quenched glass RM-02. 


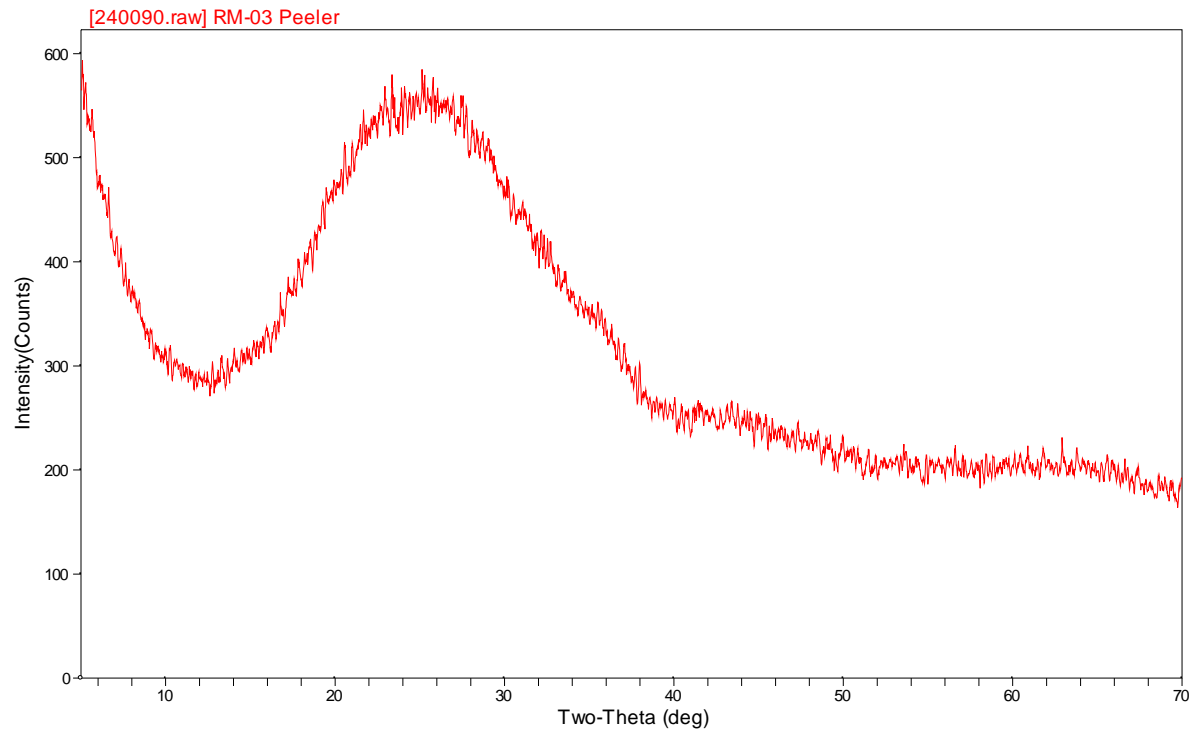

Figure A-3. XRD results for quenched glass RM-03.

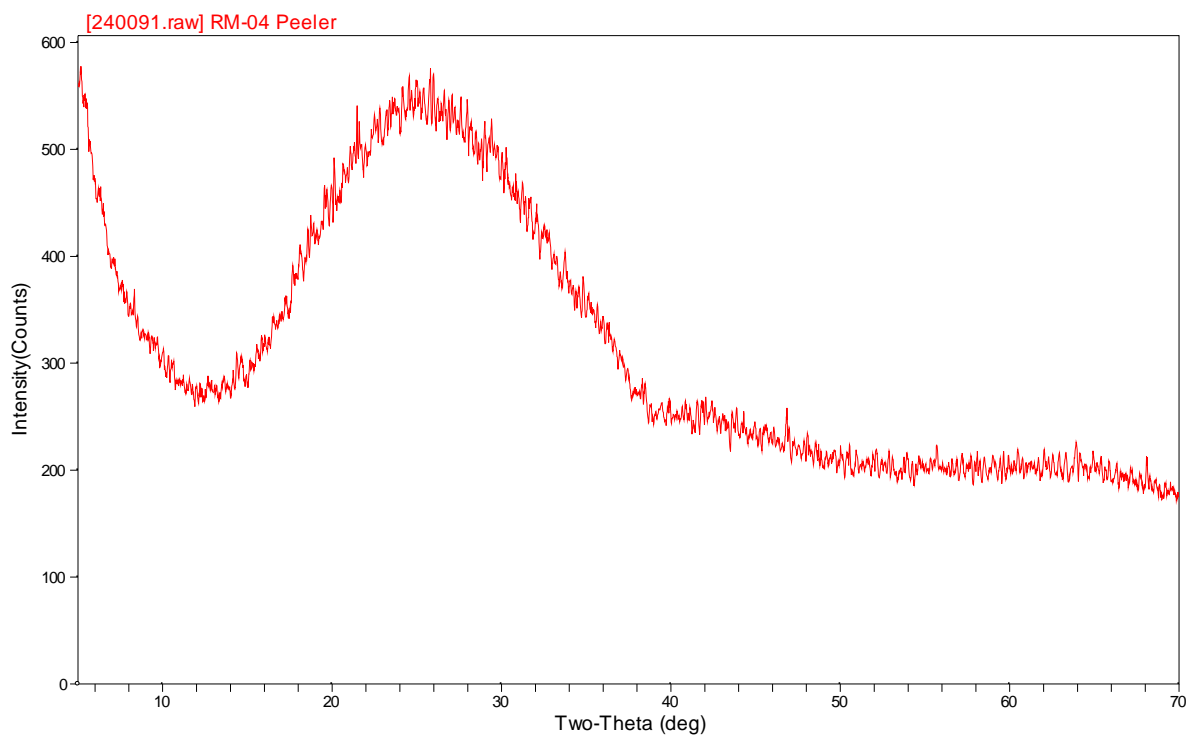

Figure A-4. XRD results for quenched glass RM-04. 


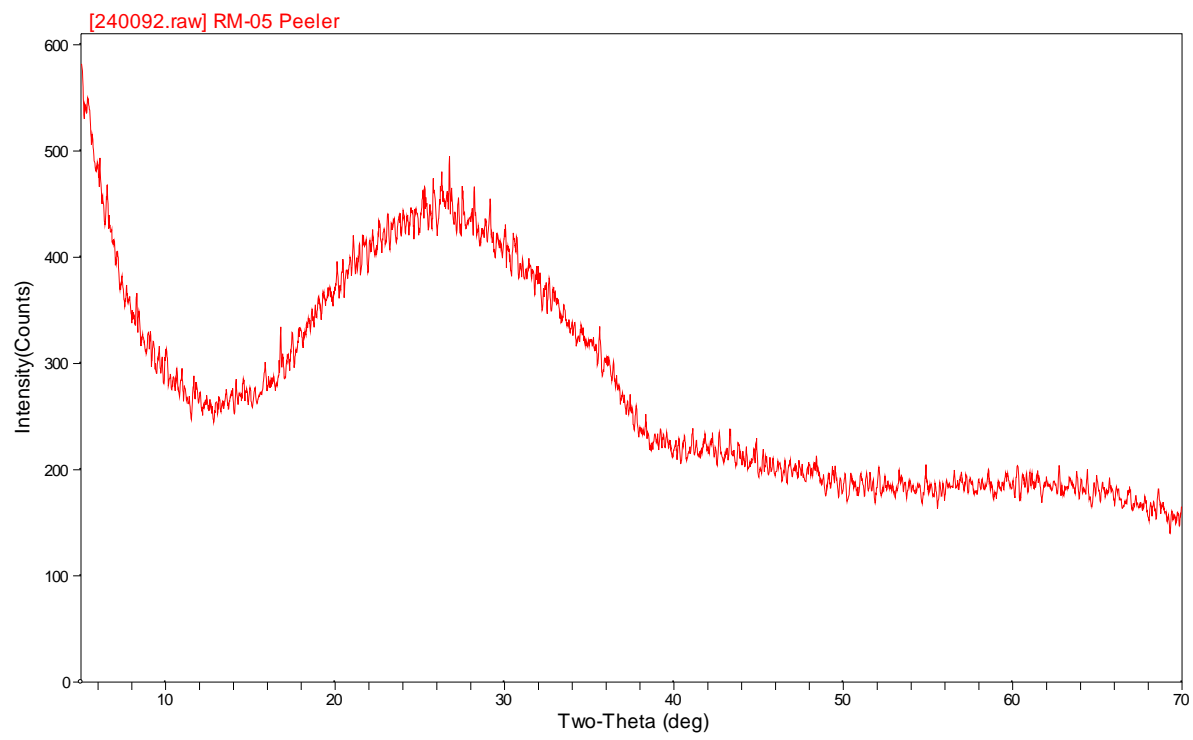

Figure A-5. XRD results for quenched glass RM-05.

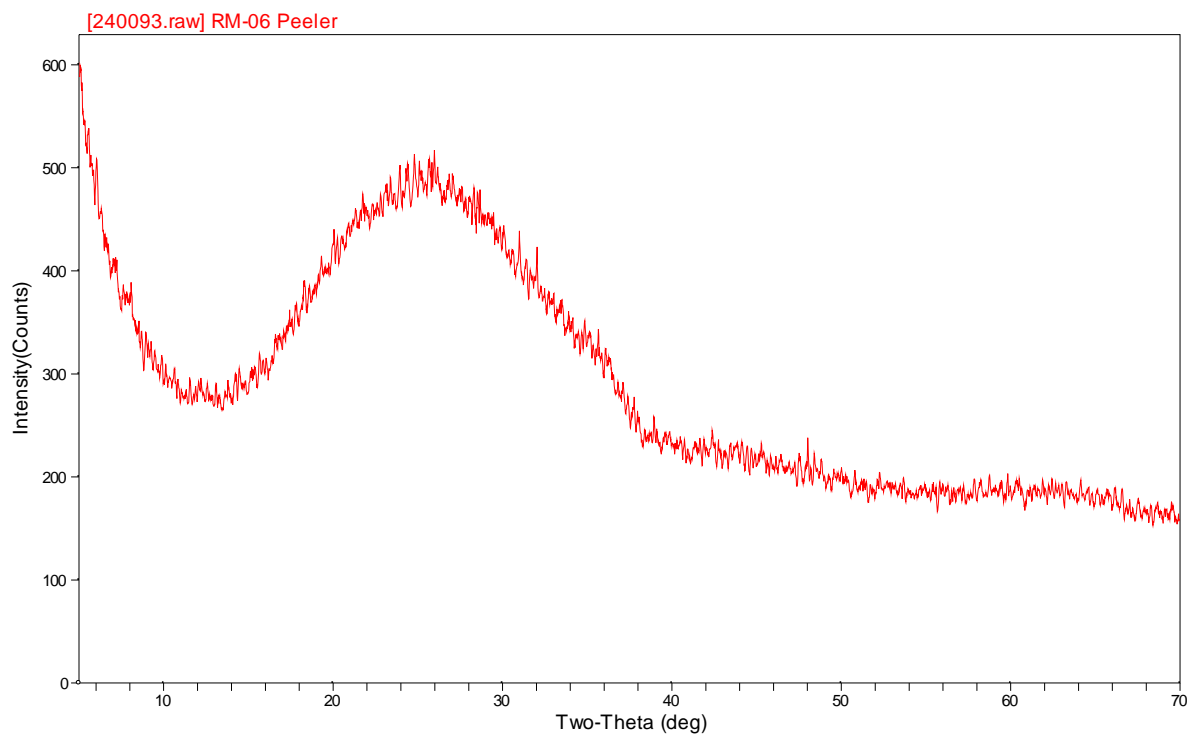

Figure A-6. XRD results for quenched glass RM-06. 


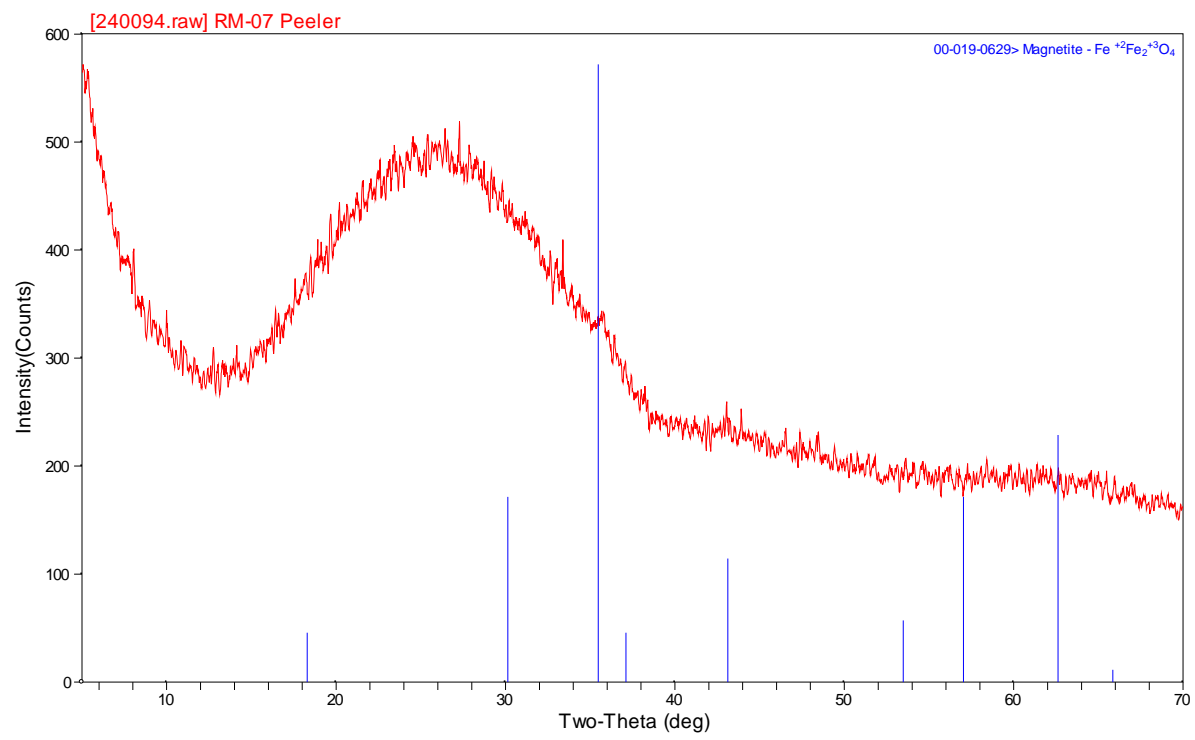

Figure A-7. XRD results for quenched glass RM-07.

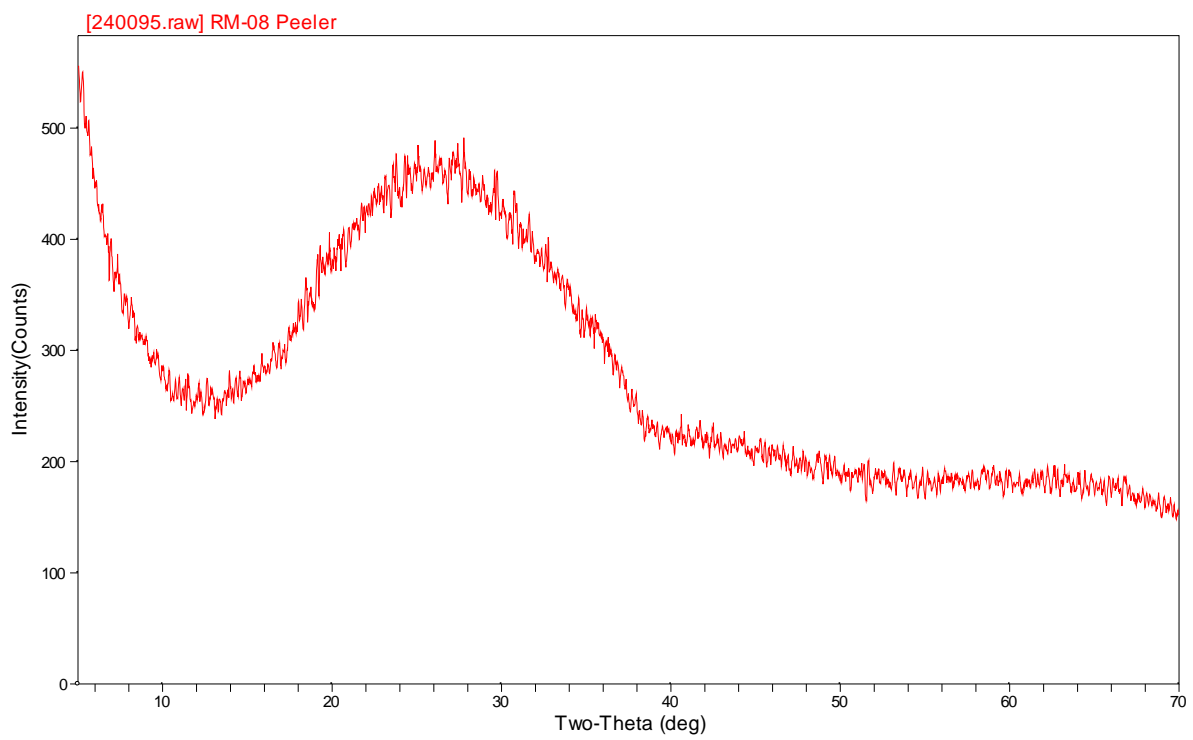

Figure A-8. XRD results for quenched glass RM-08. 


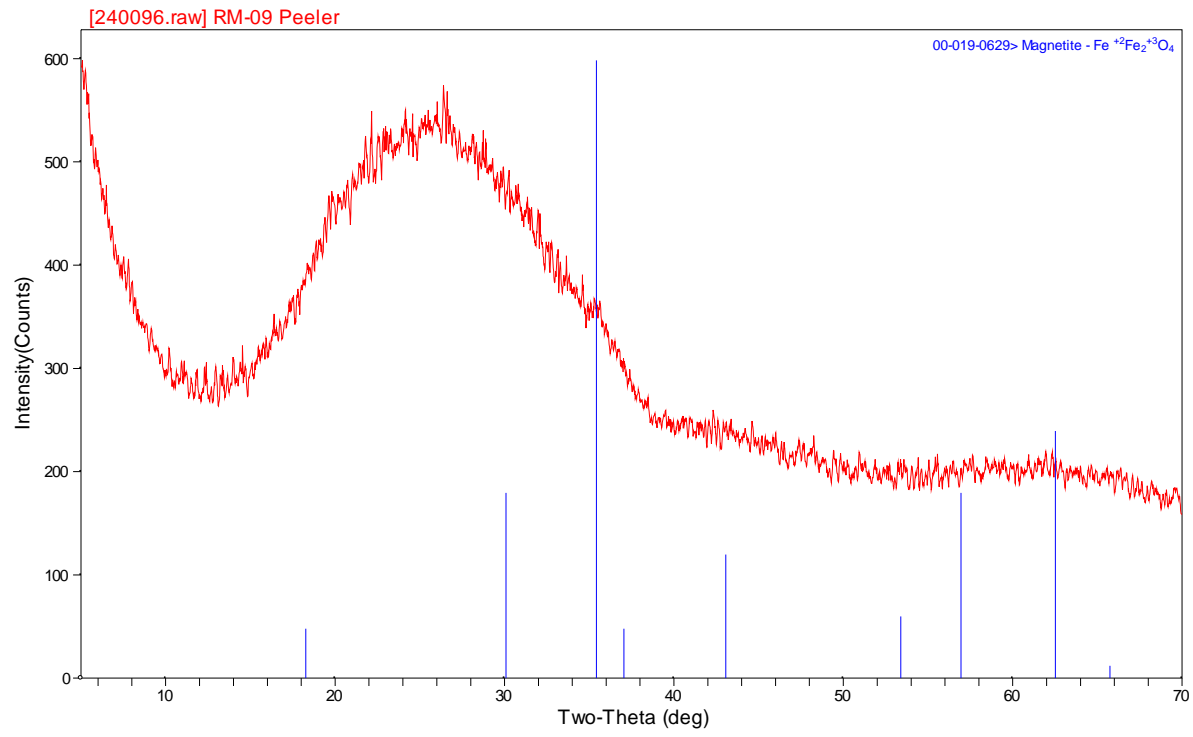

Figure A-9. XRD results for quenched glass RM-09.

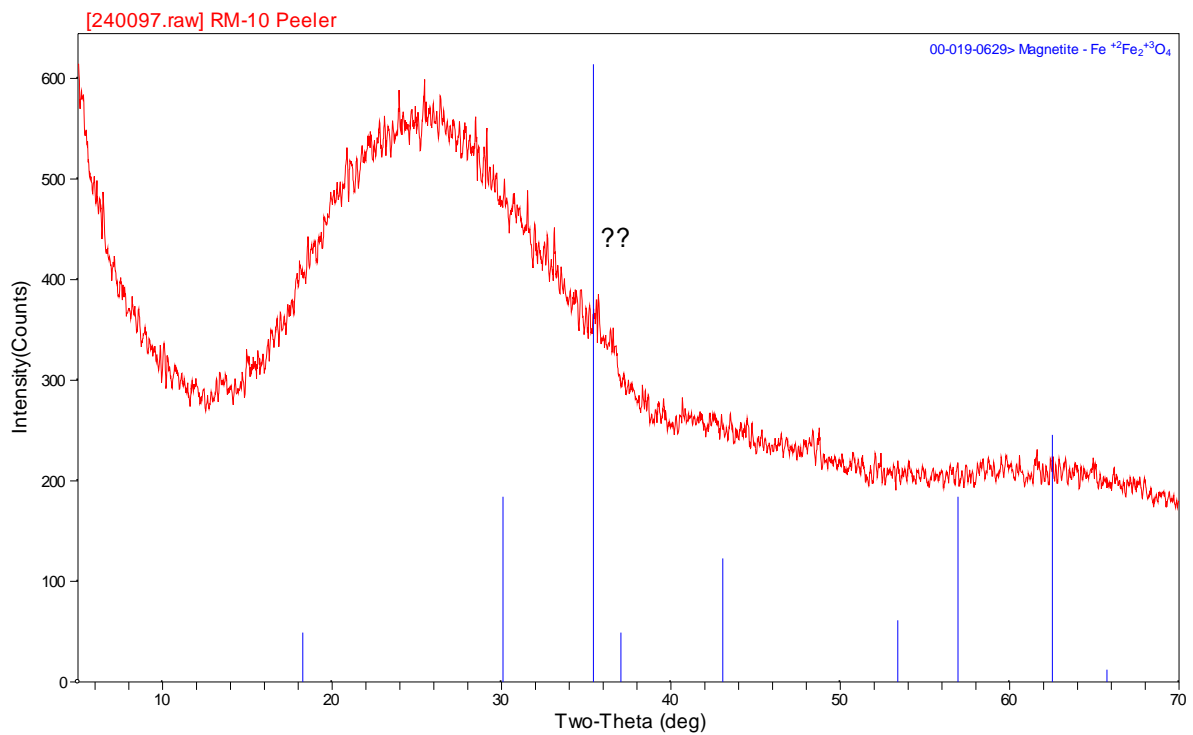

Figure A-10. XRD results for quenched glass RM-10. 


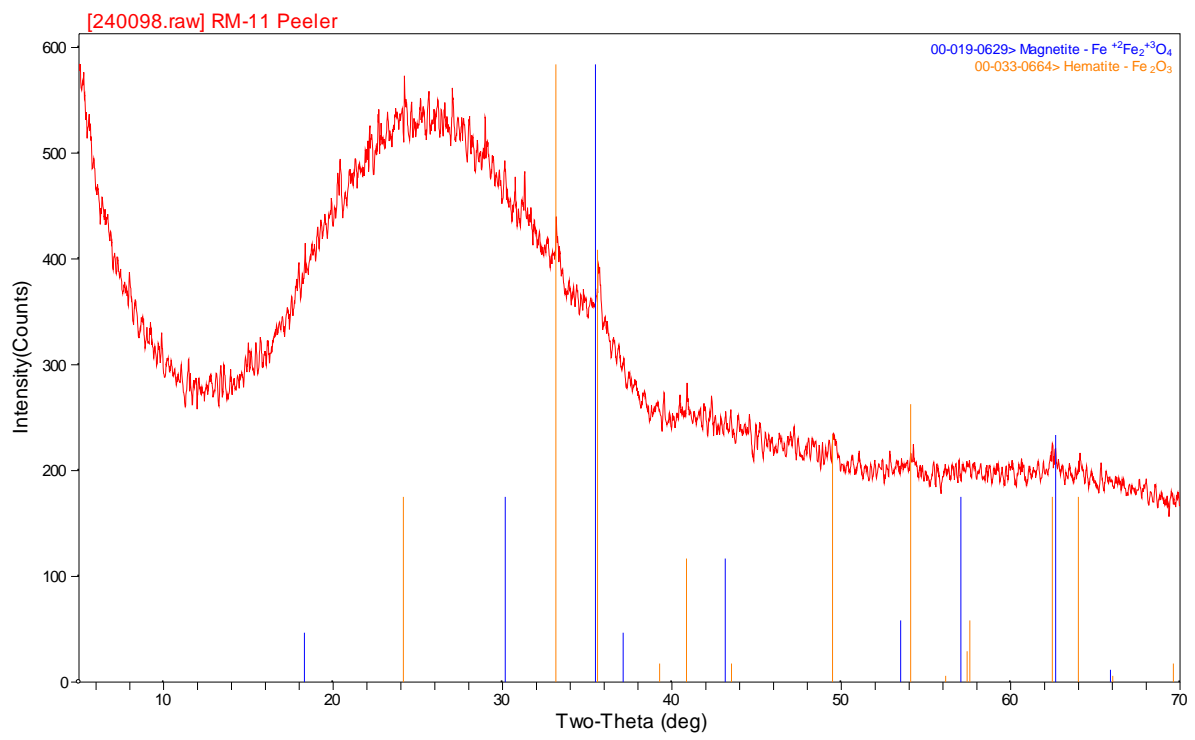

Figure A-11. XRD results for quenched glass RM-11.

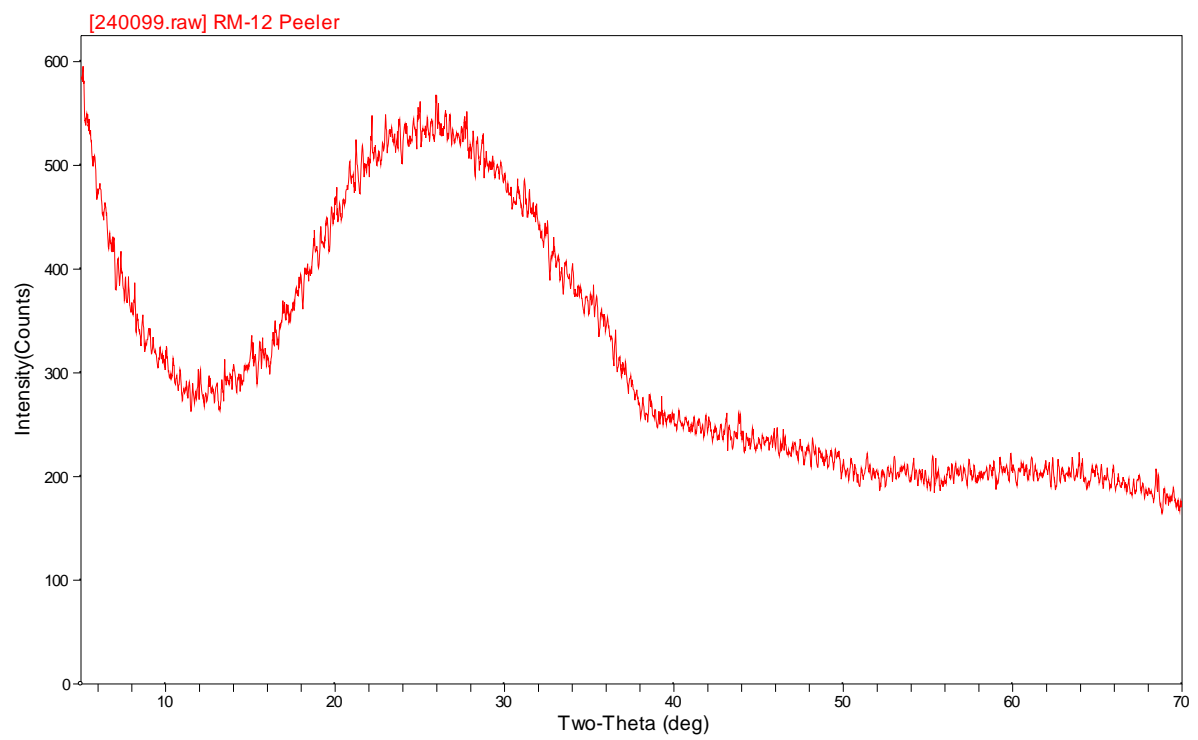

Figure A-12. XRD results for quenched glass RM-12. 


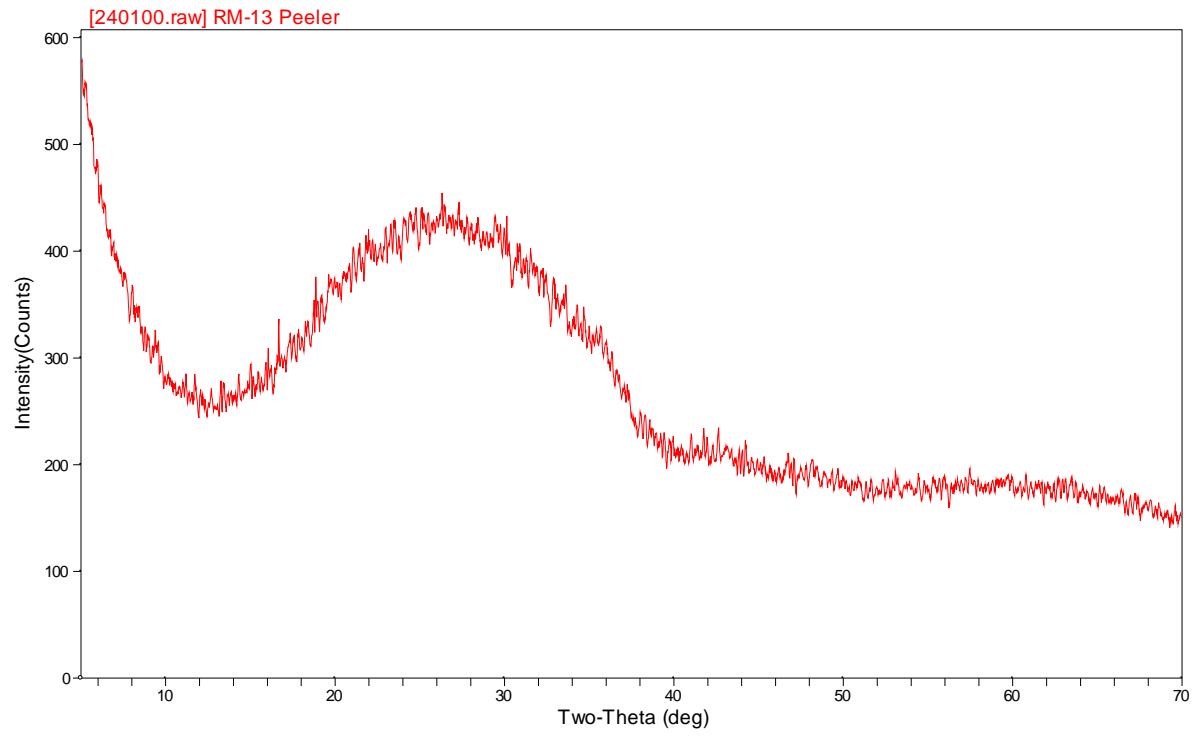

Figure A-13. XRD results for quenched glass RM-13.

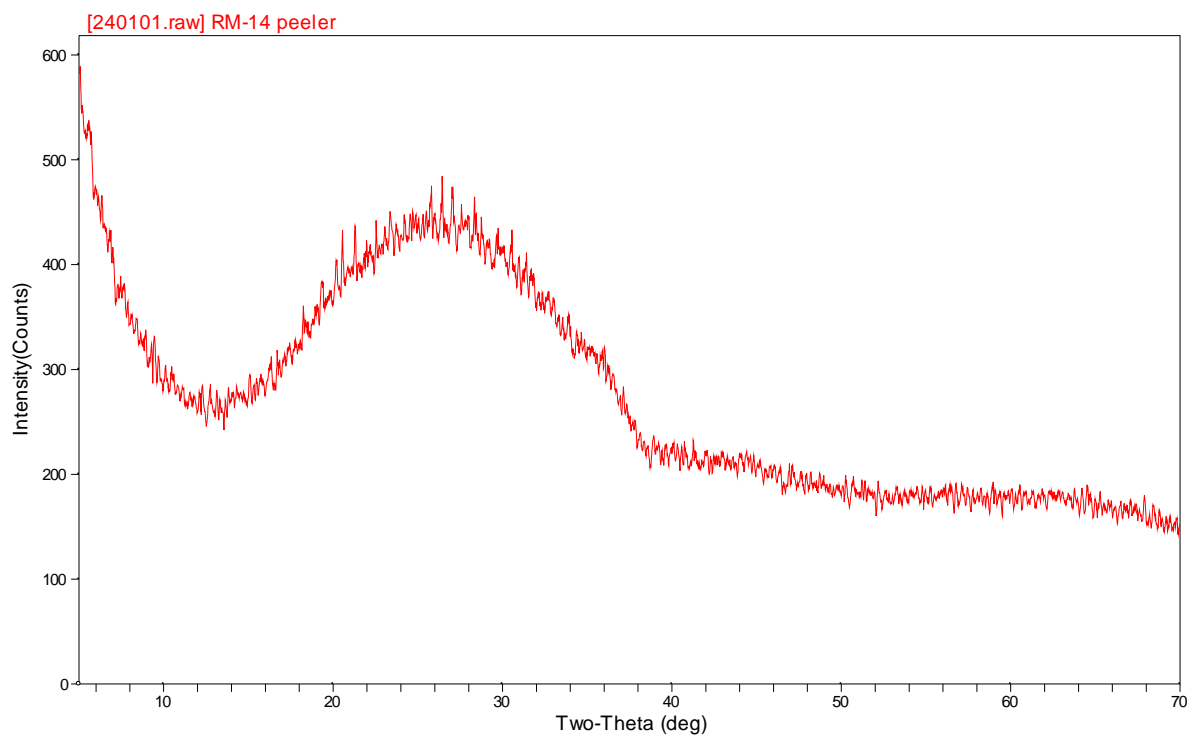

Figure A-14. XRD results for quenched glass RM-14. 


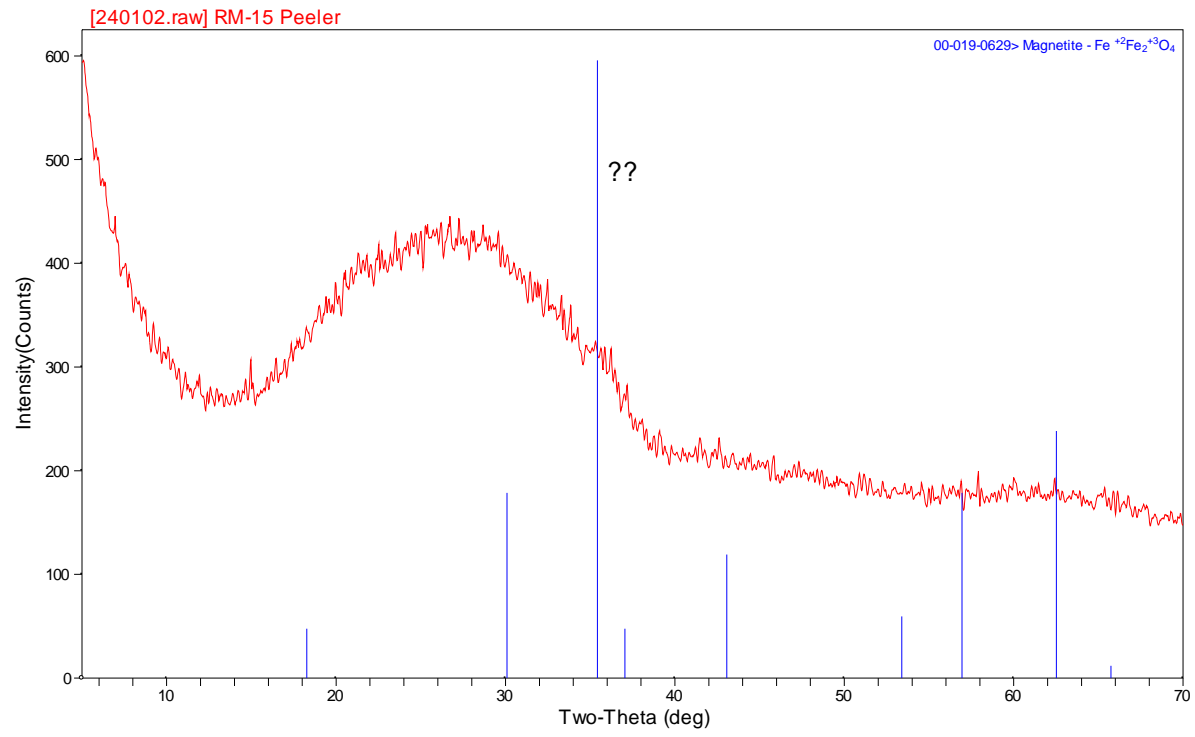

Figure A-15. XRD results for quenched glass RM-15.

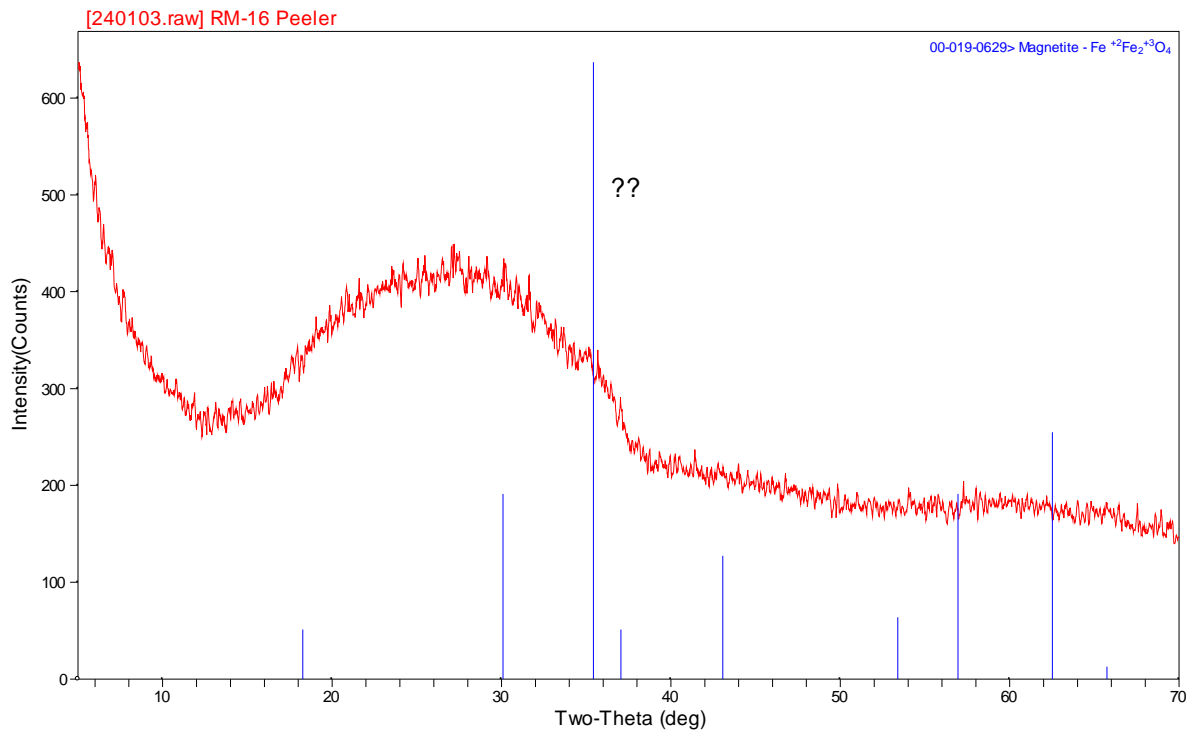

Figure A-16. XRD results for quenched glass RM-16. 
WSRC-STI-2007-00363

Revision 0

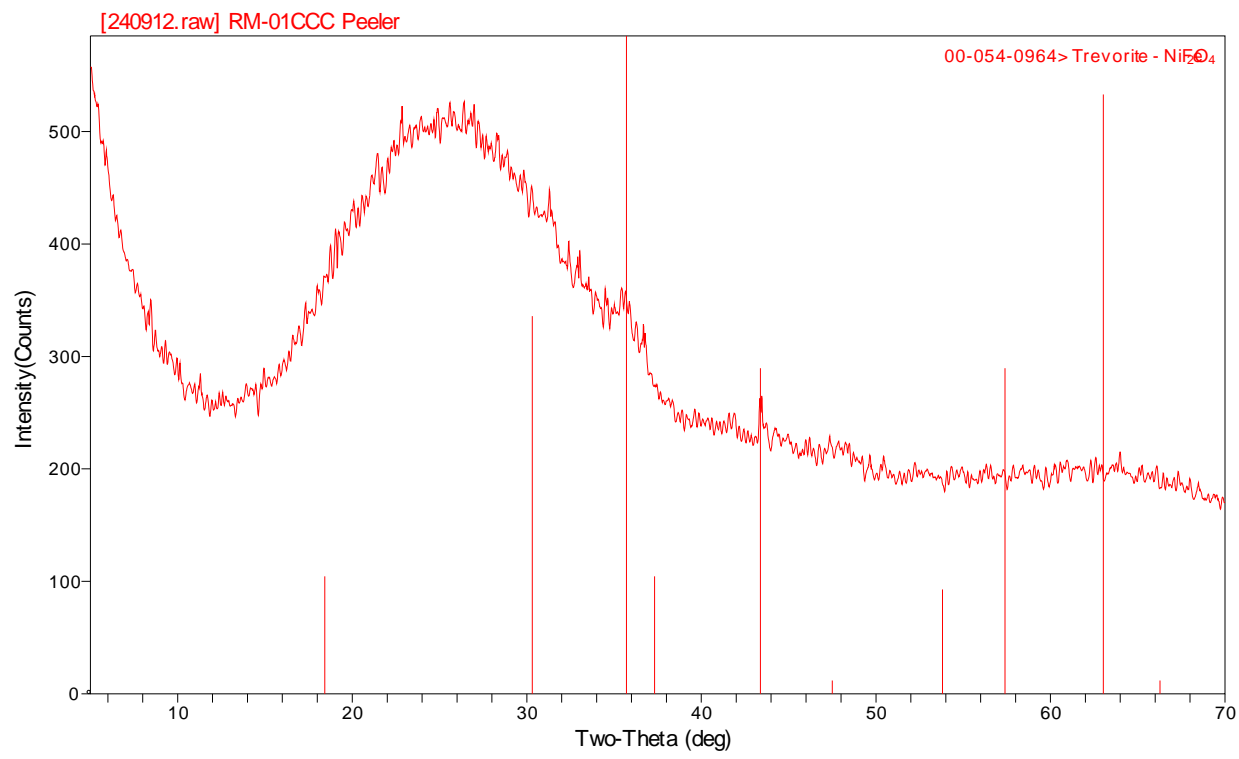

Figure A-17. XRD results for CCC glass RM-01.

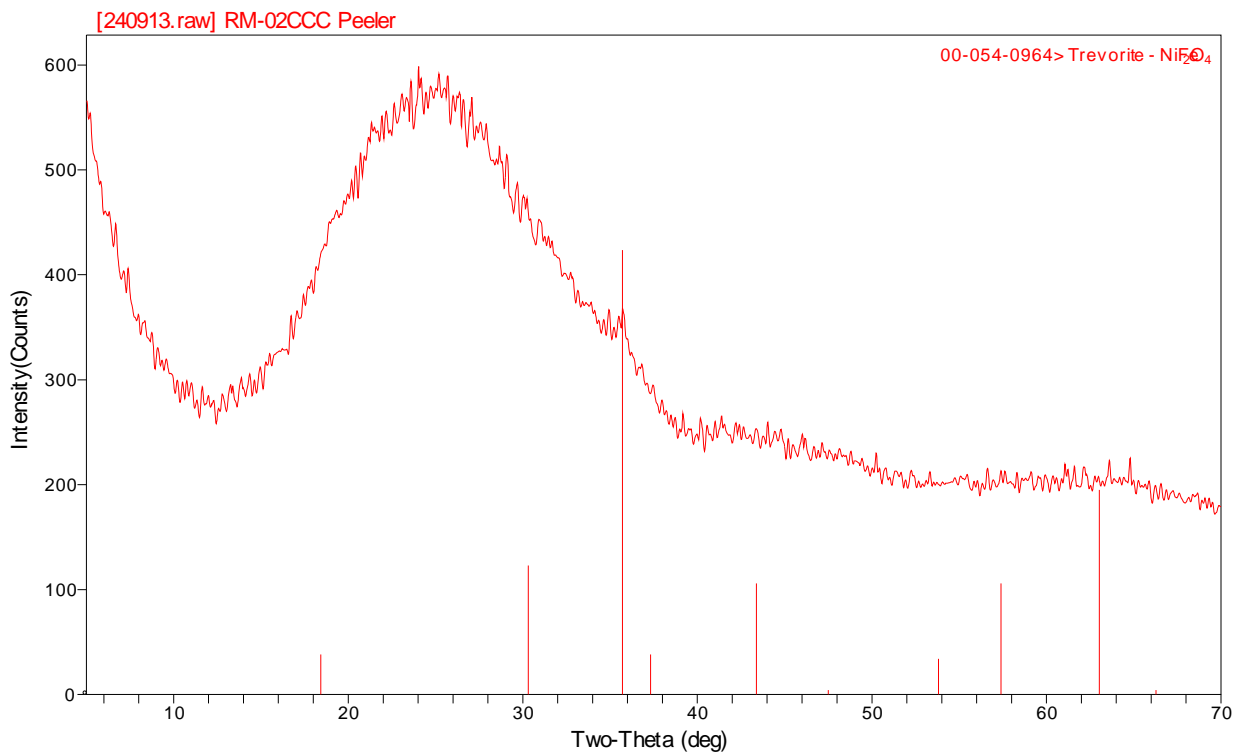

Figure A-18. XRD results for CCC glass RM-02. 
WSRC-STI-2007-00363

Revision 0

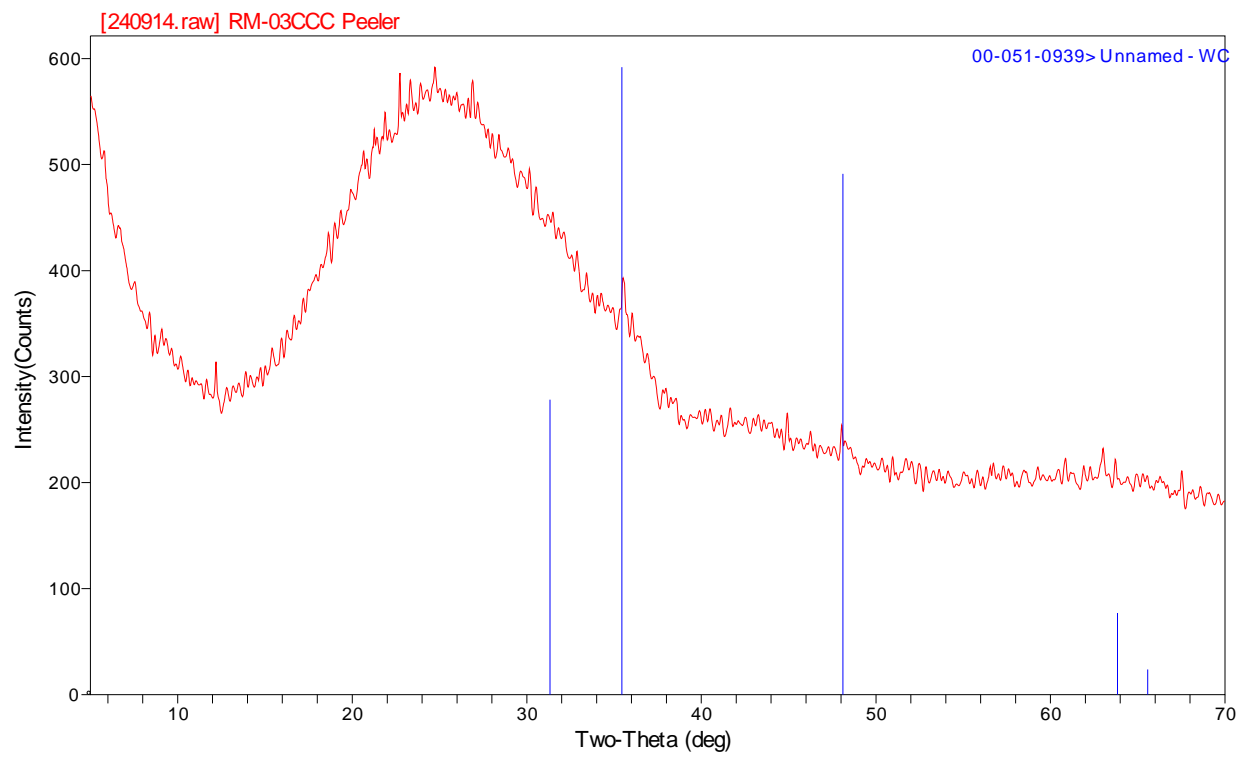

Figure A-19. XRD results for CCC glass RM-03.

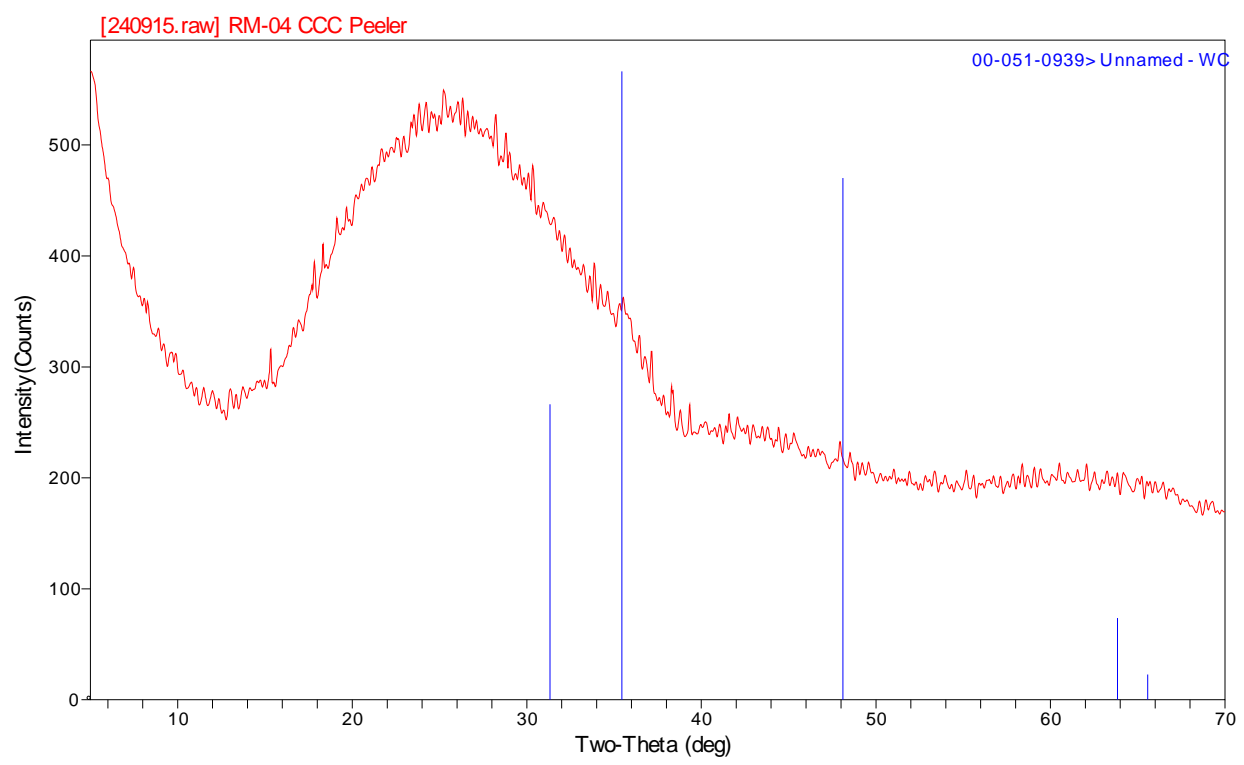

Figure A-20. XRD results for CCC glass RM-04. 
WSRC-STI-2007-00363

Revision 0

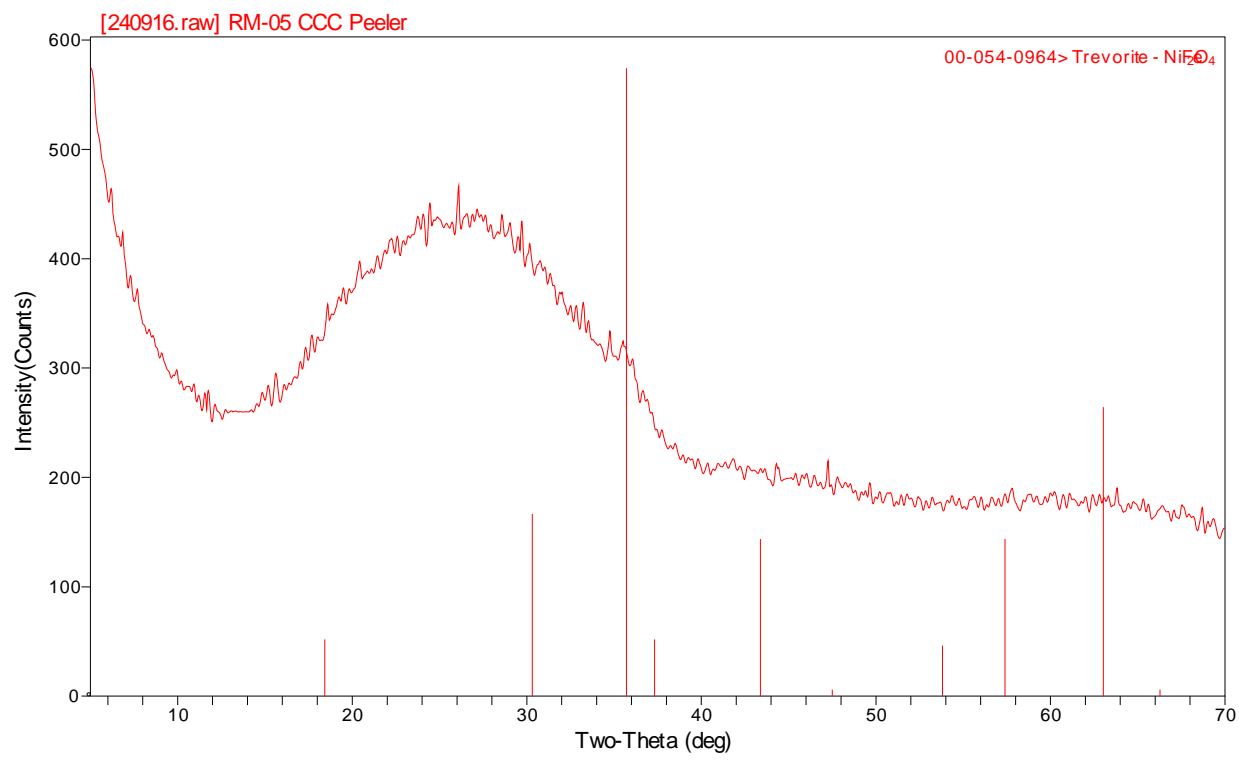

Figure A-21. XRD results for CCC glass RM-05.

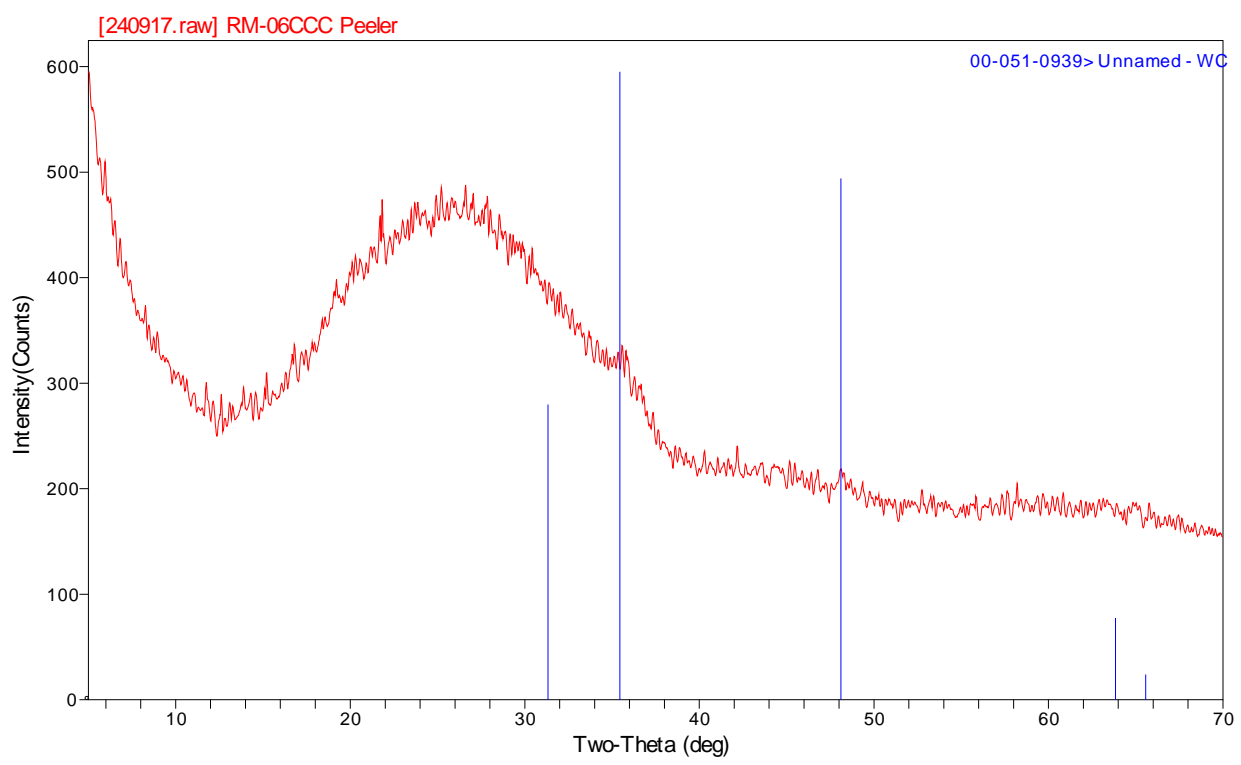

Figure A-22. XRD results for CCC glass RM-06. 


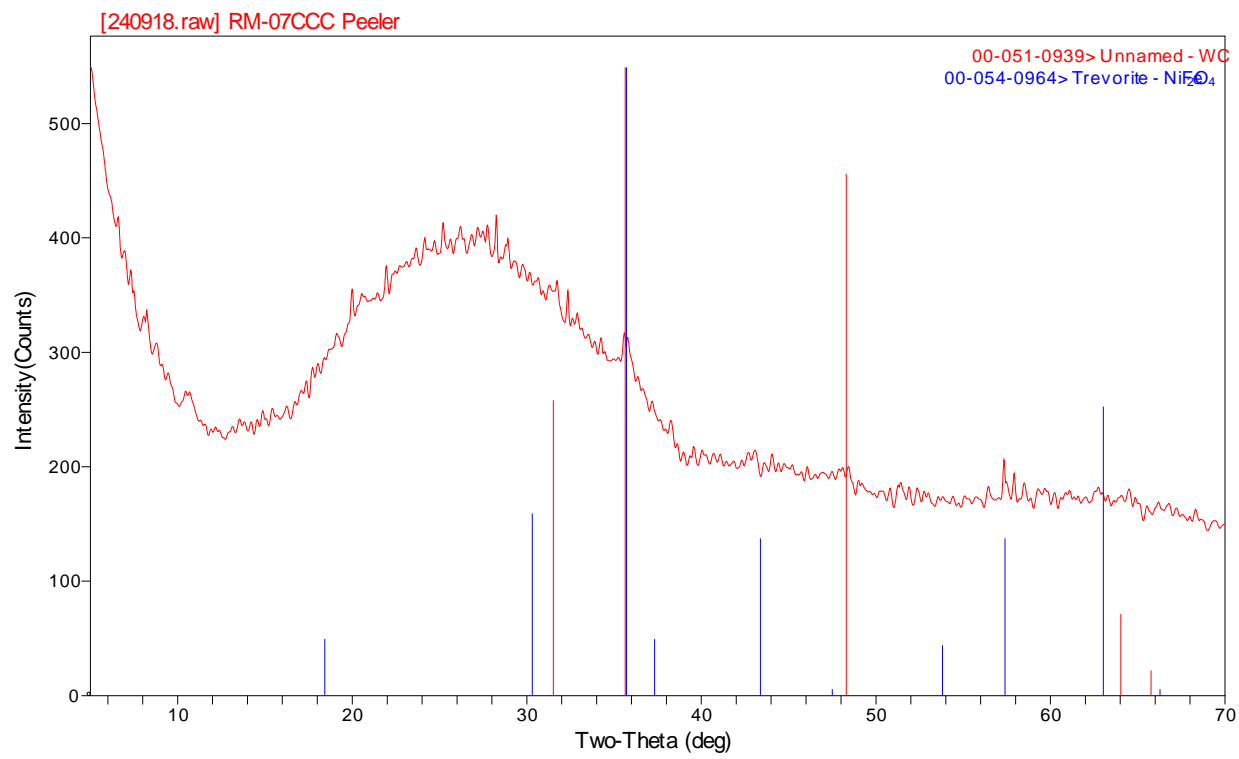

Figure A-23. XRD results for CCC glass RM-07.

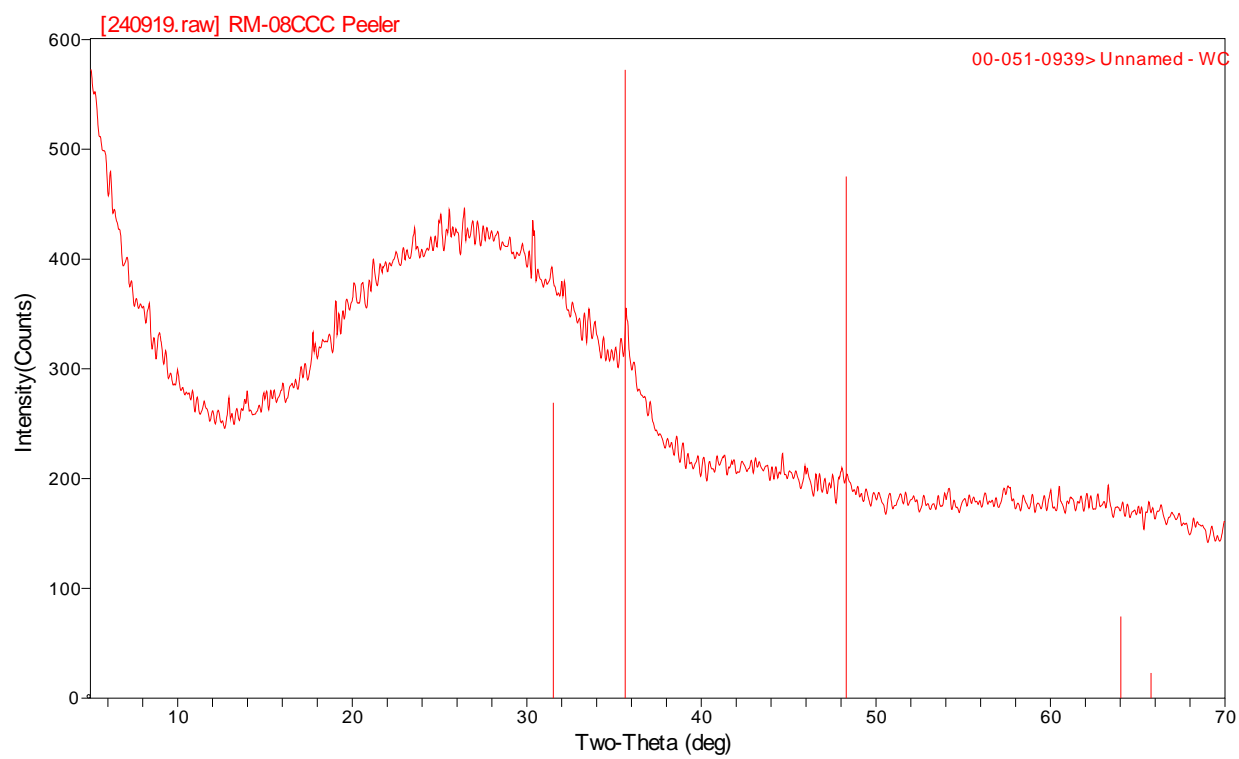

Figure A-24. XRD results for CCC glass RM-08. 
WSRC-STI-2007-00363

Revision 0

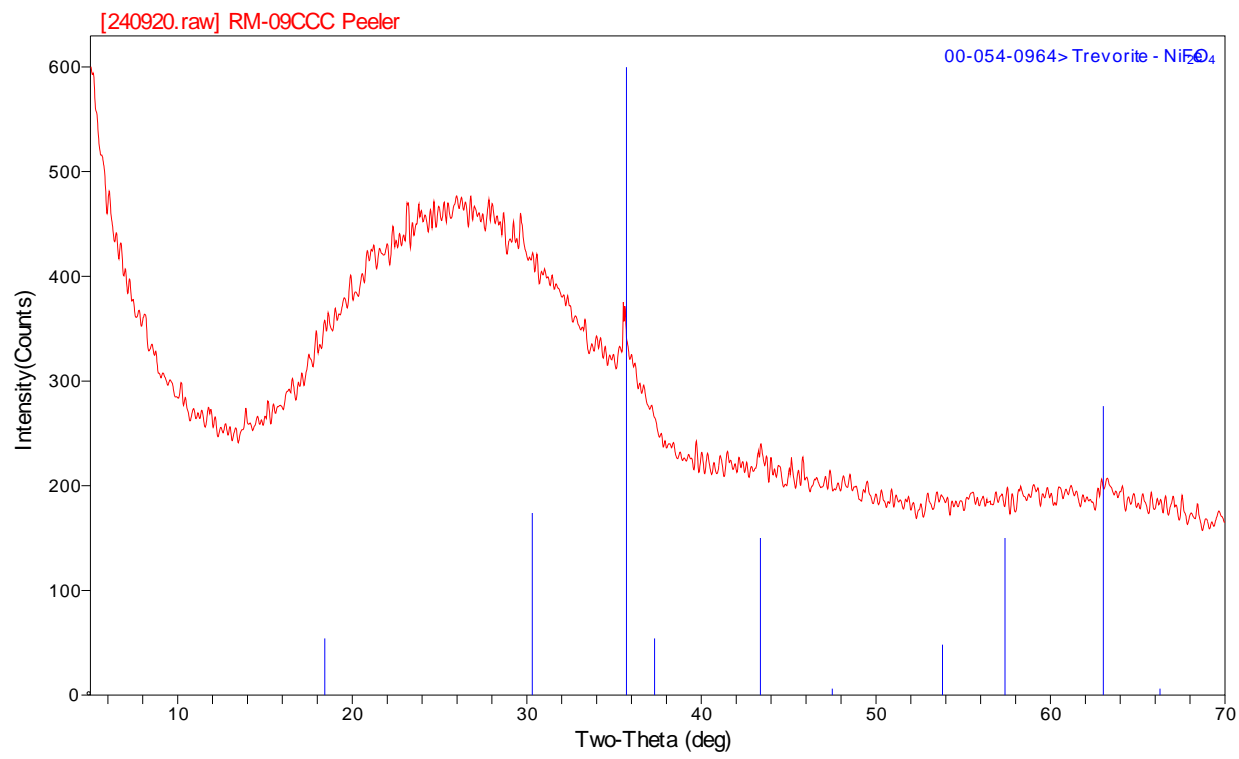

Figure A-25. XRD results for CCC glass RM-09.

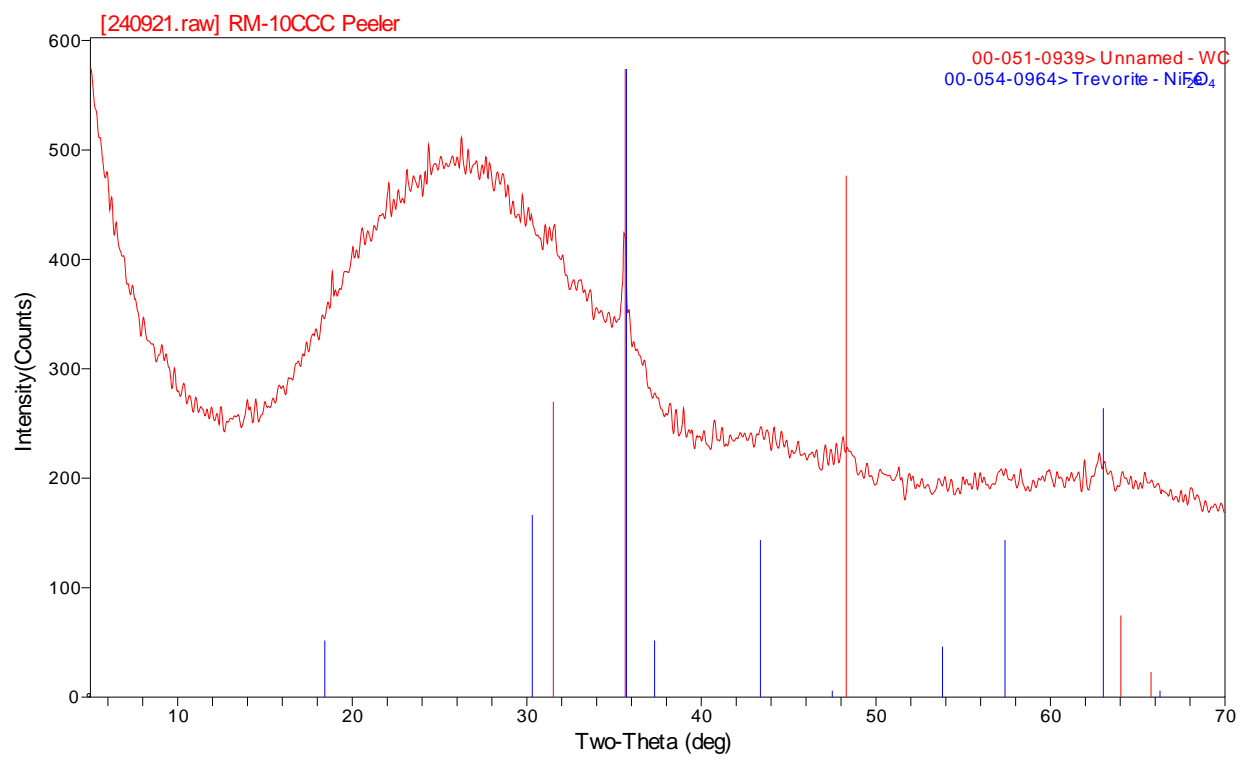

Figure A-26. XRD results for CCC glass RM-10. 
WSRC-STI-2007-00363

Revision 0

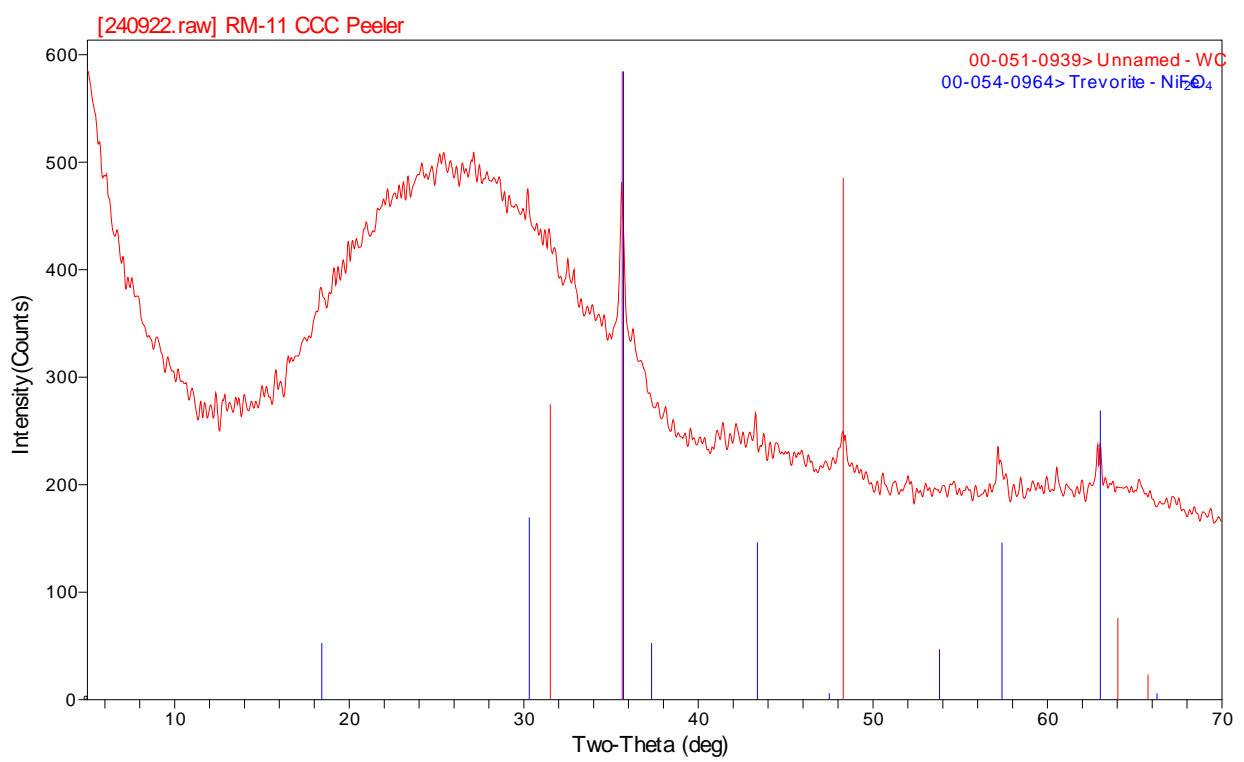

Figure A-27. XRD results for CCC glass RM-11.

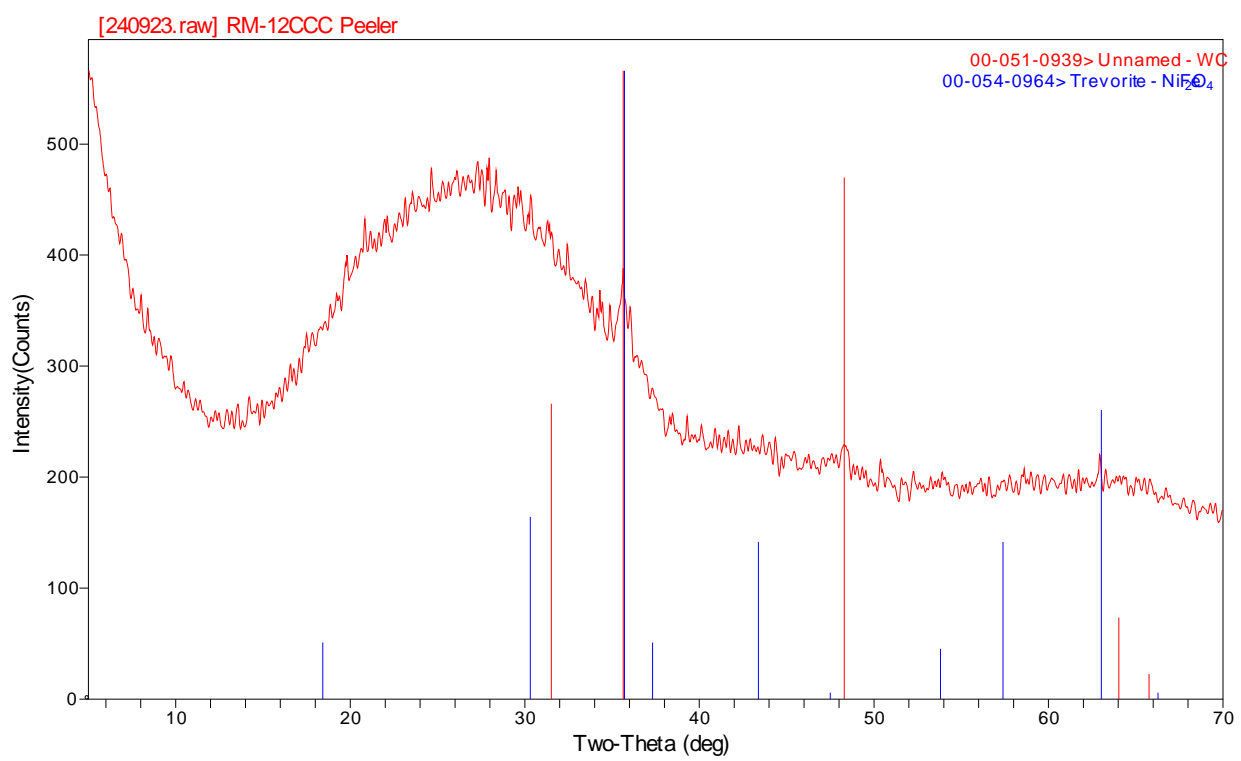

Figure A-28. XRD results for CCC glass RM-12. 


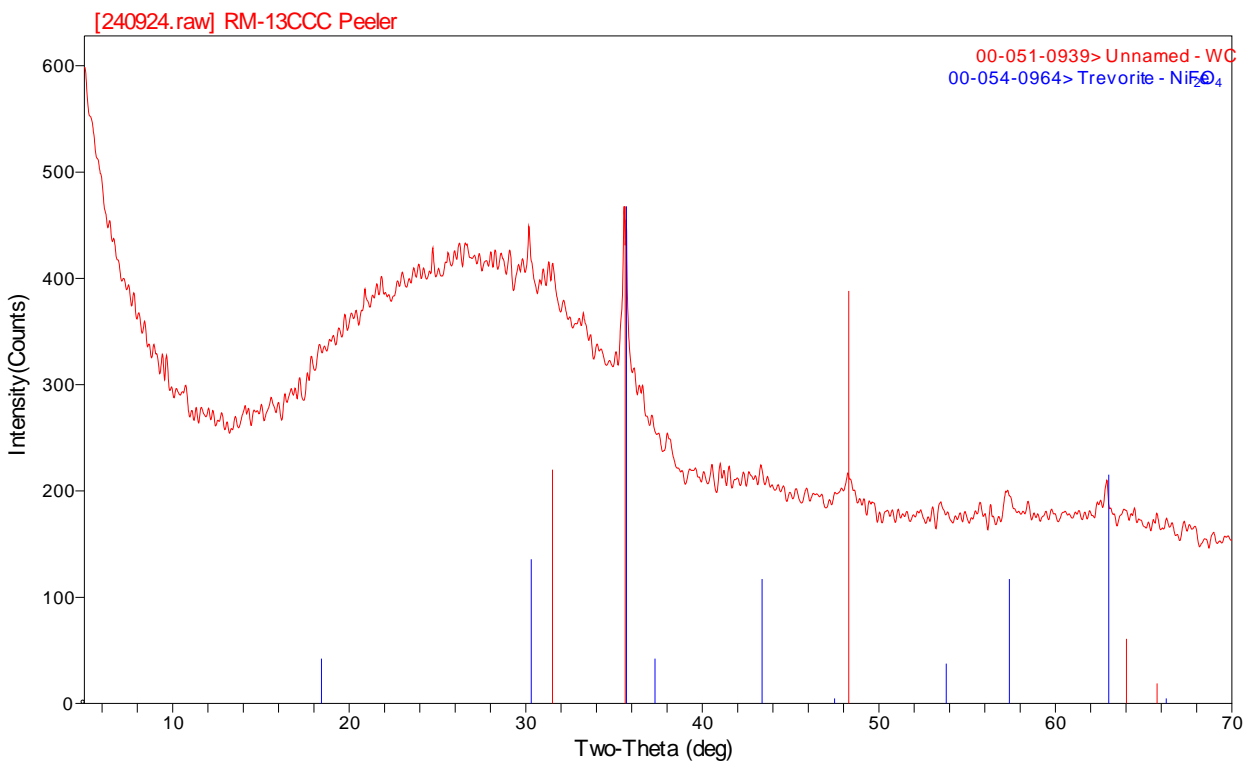

Figure A-29. XRD results for CCC glass RM-13.

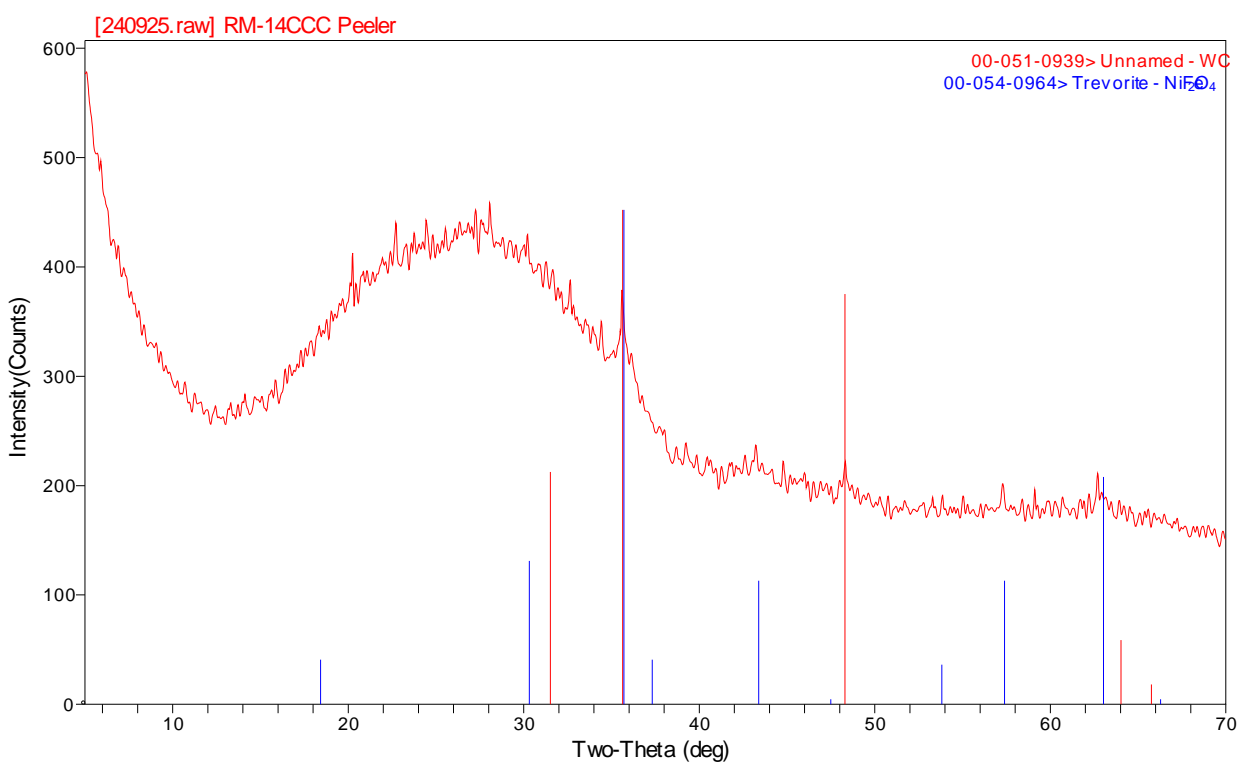

Figure A-30. XRD results for CCC glass RM-14. 


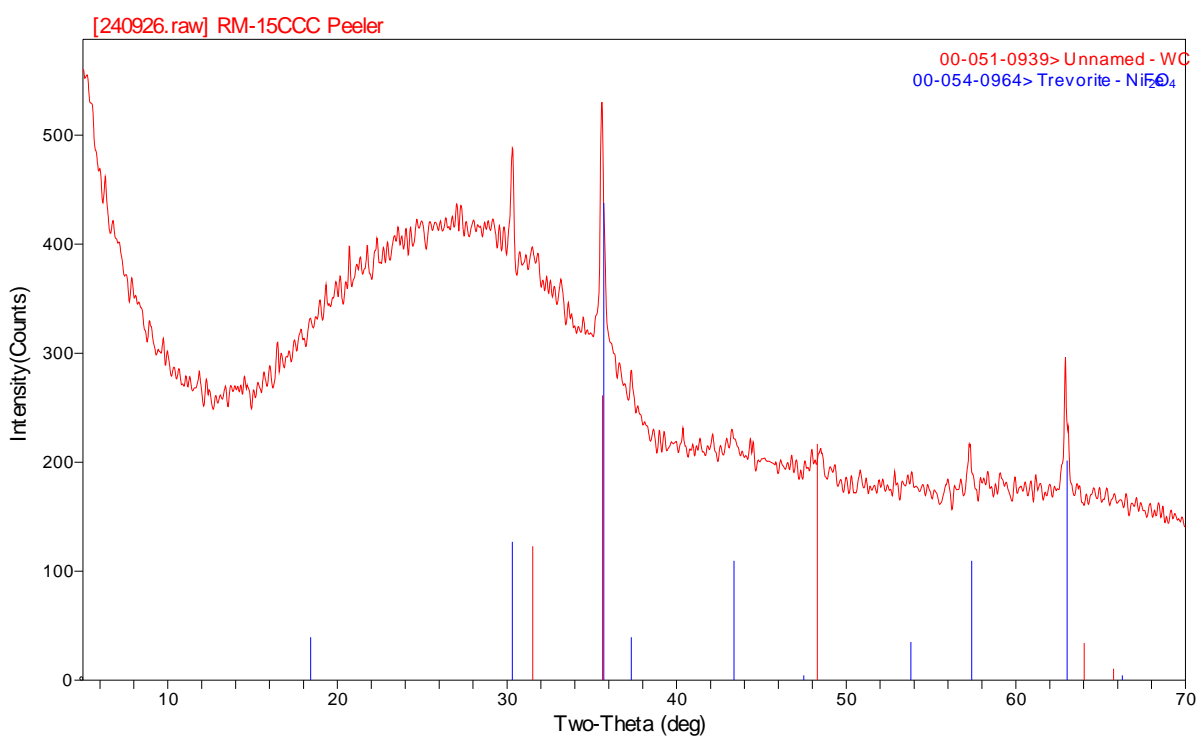

Figure A-31. XRD results for CCC glass RM-15.

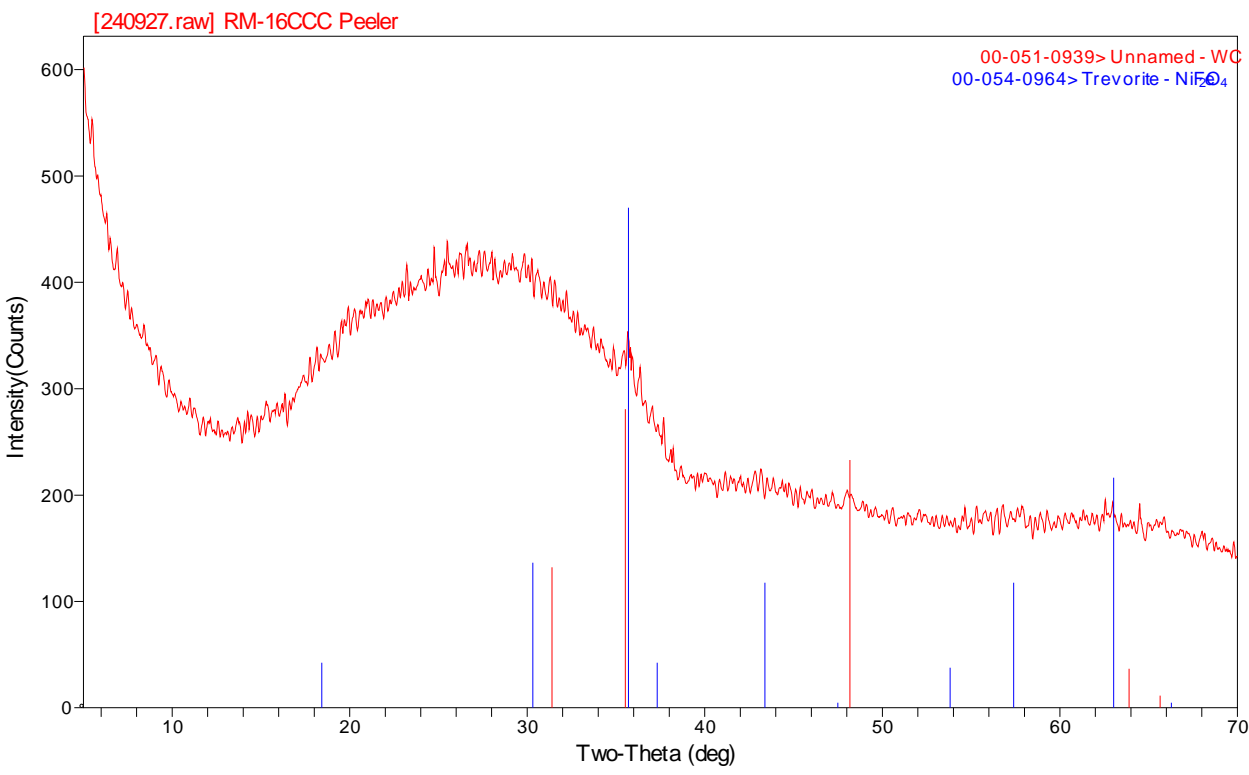

Figure A-32. XRD results for CCC glass RM-16. 
WSRC-STI-2007-00363

Revision 0

This page intentionally left blank. 